\title{
Switching the Spin State of Diphenylcarbene via Halogen Bonding
}

Stefan Henkel, ${ }^{\dagger}$ Paolo Costa, ${ }^{\dagger}$ Linda Klute, ${ }^{\dagger}$ Pandian Sokkar, ${ }^{\ddagger}$ Miguel Fernandez-Oliva, ${ }^{\ddagger}$ Walter Thiel, ${ }^{\ddagger}$ Elsa Sanchez-Garcia, ${ }^{* \neq}$ and Wolfram Sander ${ }^{*,+}$

${ }^{+}$Lehrstuhl für Organische Chemie II, Ruhr-Universität Bochum, 44801 Bochum, Germany

${ }^{\ddagger}$ Max-Planck-Institut für Kohlenforschung, 45470 Mülheim an der Ruhr, Germany

\section{Contents}

Spectroscopic Data

Computational Results 


\section{Spectroscopic Data}

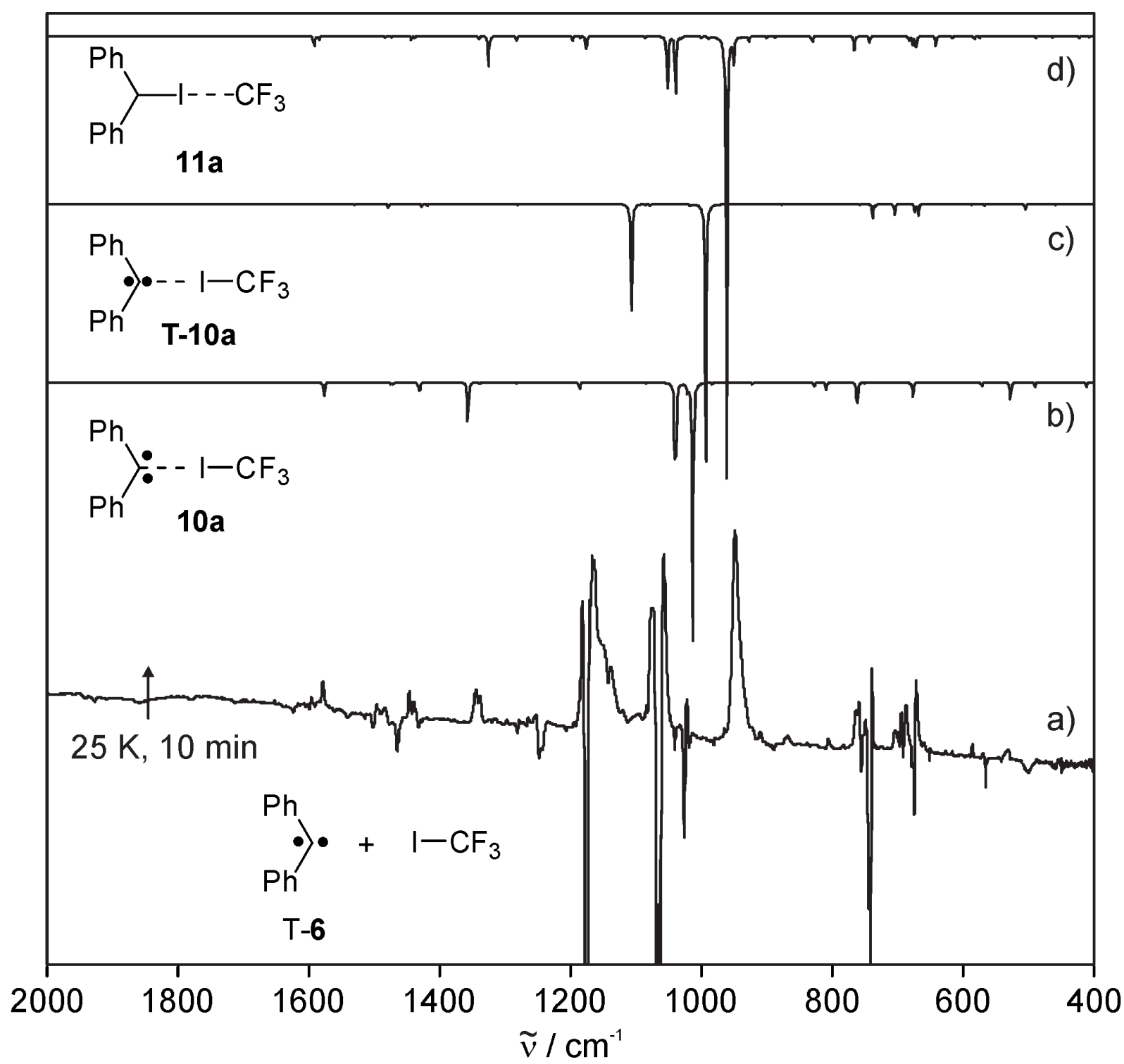

Figure S1. IR spectrum of the reaction of DPC 6 with ICF 3 . a) IR difference spectrum obtained upon annealing of an argon matrix containing triplet carbene 6 and $1 \%$ of ICF 3 to $25 \mathrm{~K}$ for $10 \mathrm{~min}$. b) Calculated IR spectrum of singlet complex 10a (B97-D3/def2-TZVP). c) Calculated IR spectrum of triplet complex T-10a (B97-D3/def2-TZVP). d) Calculated IR spectrum of the complex 11a (B97-D3/def2-TZVP). 


\begin{tabular}{|c|c|c|c|c|}
\hline \multirow[b]{2}{*}{ Mode } & \multicolumn{3}{|c|}{$\tilde{v} / \mathrm{cm}^{-1}$} & \multirow[b]{2}{*}{ Assignment } \\
\hline & $\begin{array}{l}\text { Exp. } \\
\left(I_{\text {rel }}\right)^{a}\end{array}$ & $\begin{array}{l}\text { Calc. gas phase } \\
\left(\left.\right|_{\text {rel }}\right)^{b}\end{array}$ & Calc. $\mathrm{QM} / \mathrm{MM}^{d}$ & \\
\hline 20 & $504(4)$ & $489(2)$ & 488 & C-H def. (out-of-plane) \\
\hline 22 & $529(3)$ & $527(7)$ & 540 & $\begin{array}{c}\text { C-C-C def. (out-of-plane) } \\
\text { (carbene) }\end{array}$ \\
\hline 23 & $568(2)$ & $571(1)$ & 570 & Skel. Vibr. \\
\hline 27 & \multirow{2}{*}{$679\left(^{c}\right)$} & $676(5)$ & 684 & C-H def. (out-of-plane) \\
\hline 28 & & $677(1)$ & 686 & C-H def. (out-of-plane) \\
\hline 31 & $764(11)$ & 761(9) & 765 & C-H def. (out-of-plane) \\
\hline 33 & $838(3)$ & $827(2)$ & 833 & C-H def. (out-of-plane) \\
\hline 44 & $1078(100)$ & 1013(100) & 1022 & $\mathrm{~F}_{3} \mathrm{C}-\mathrm{I}$ str. \\
\hline 47 & \multirow{2}{*}{$1103(58)$} & $1038(25)$ & 1070 & C-F3 asym. str. \\
\hline 48 & & $1040(27)$ & 1078 & C-F3 asym. str. \\
\hline 60 & $1338 / 1344(64)$ & $1357(16)$ & 1355 & $\begin{array}{c}\text { C-C-C asym. str. } \\
\text { (carbene) }\end{array}$ \\
\hline 61 & \multirow{2}{*}{$1439(3)$} & $1430(3)$ & 1418 & C=C str. Ring \\
\hline 62 & & 1432(2) & 1421 & $\mathrm{C}=\mathrm{C}$ str. Ring \\
\hline 63 & \multirow{2}{*}{$1496(5)$} & 1471(1) & 1467 & $\mathrm{C}=\mathrm{C}$ str. Ring \\
\hline 64 & & 1474(1) & 1475 & $\mathrm{C}=\mathrm{C}$ str. Ring \\
\hline 67 & $1578(20)$ & $1576(6)$ & 1570 & $\mathrm{C}=\mathrm{C}$ str. Ring \\
\hline
\end{tabular}

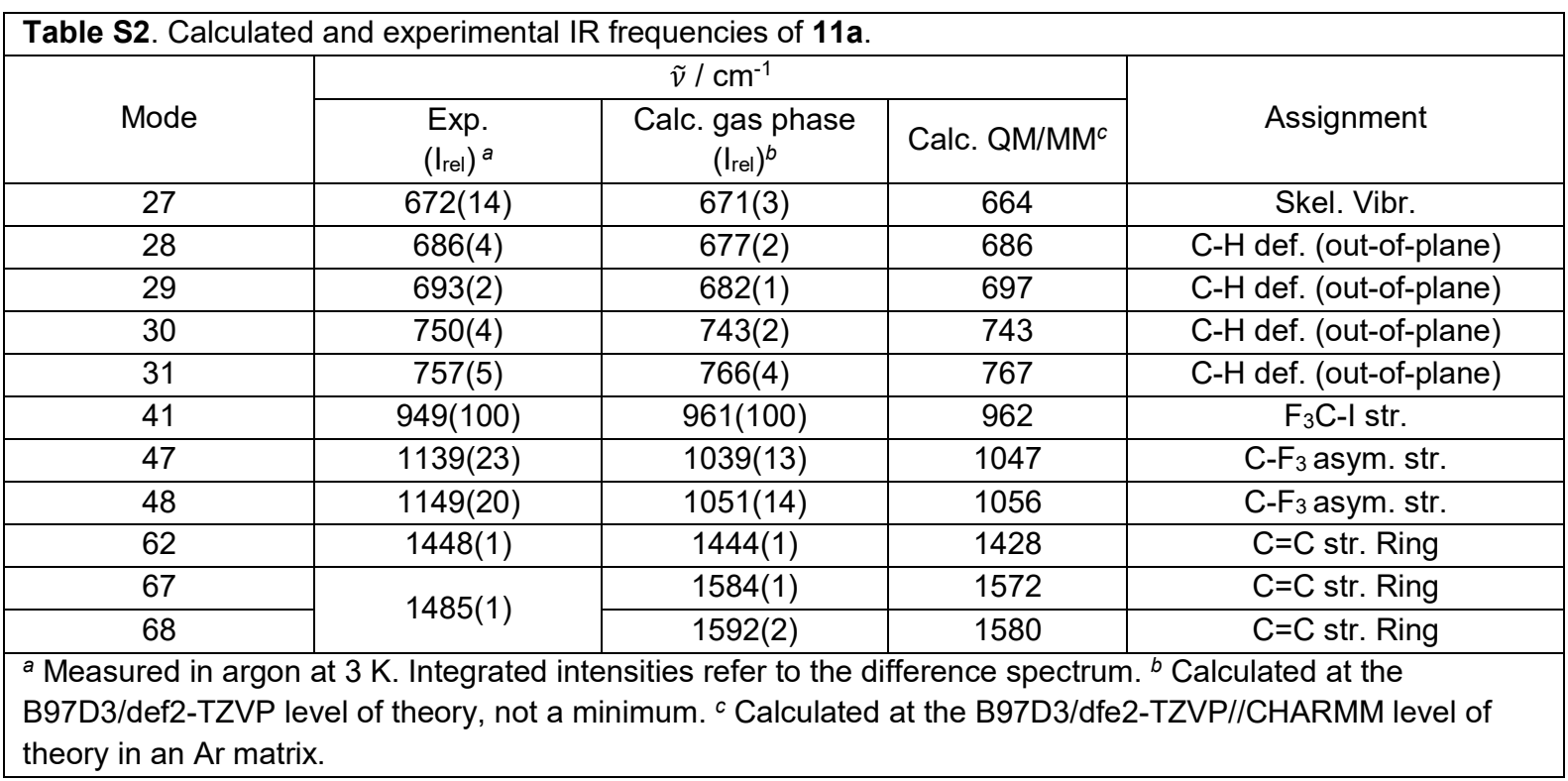




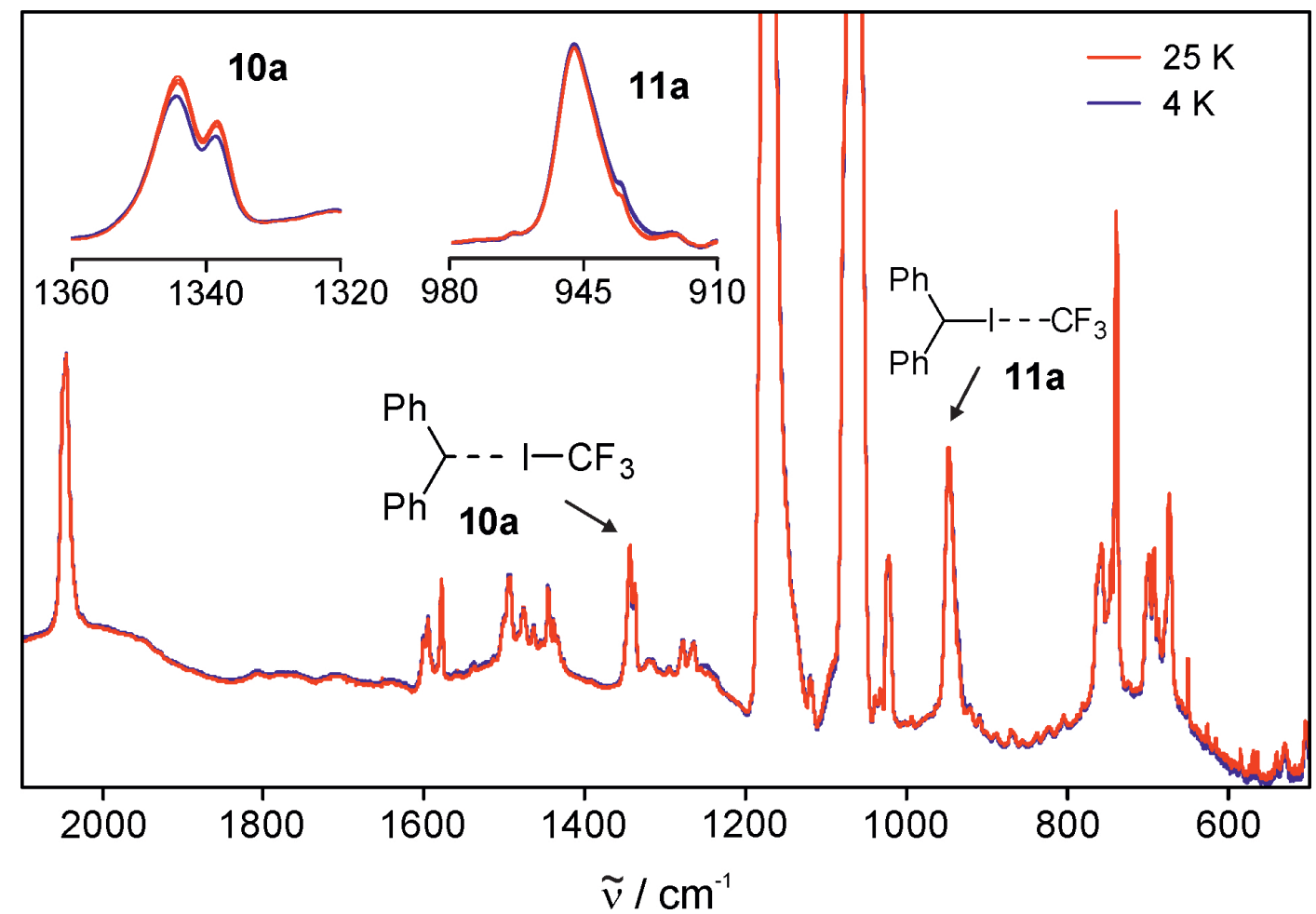

Figure S2. IR spectra showing the interconversion between complexes 10a and 11a upon cycling the temperature between $25 \mathrm{~K}$ (red spectra) and $4 \mathrm{~K}$ (blue spectra). Insets show the characteristic signals of 10a and 11a.

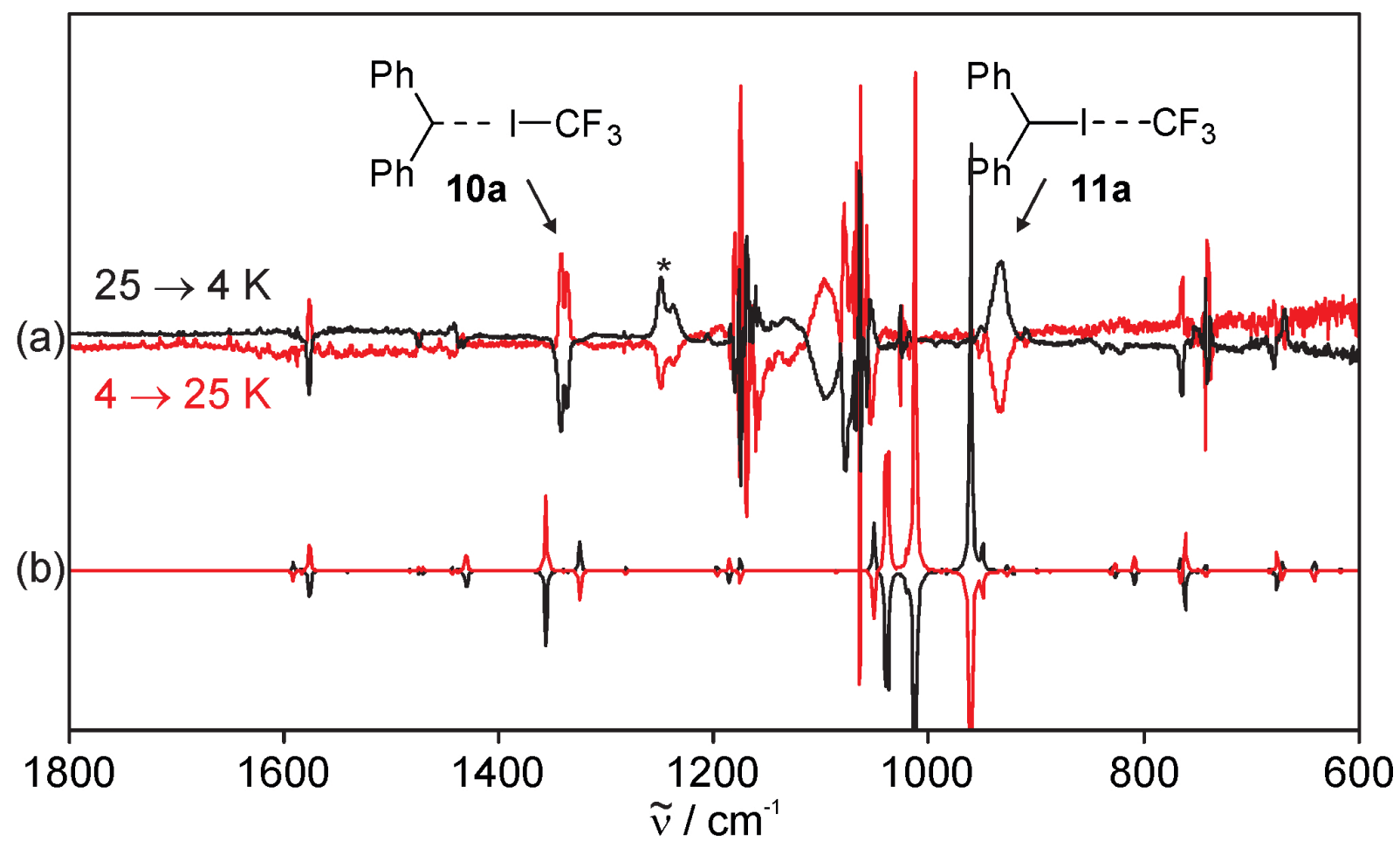

Figure S3. IR difference spectra showing the interconversion between complexes 10a and 11a upon cycling the temperature between 25 and $4 \mathrm{~K}$. a) IR difference spectrum obtained on warming to $25 \mathrm{~K}$ (red) and on cooling back to $4 \mathrm{~K}$ (black). Bands of the $\mathrm{CF}_{3}$ radical are labeled with an asterisk. b) Calculated IR difference spectra (B97D3/def2-TZVP) of the conversion of $11 \mathrm{a}$ to $10 \mathrm{a}$ (red) and of $10 \mathrm{a}$ to $11 \mathrm{a}$ (black). 


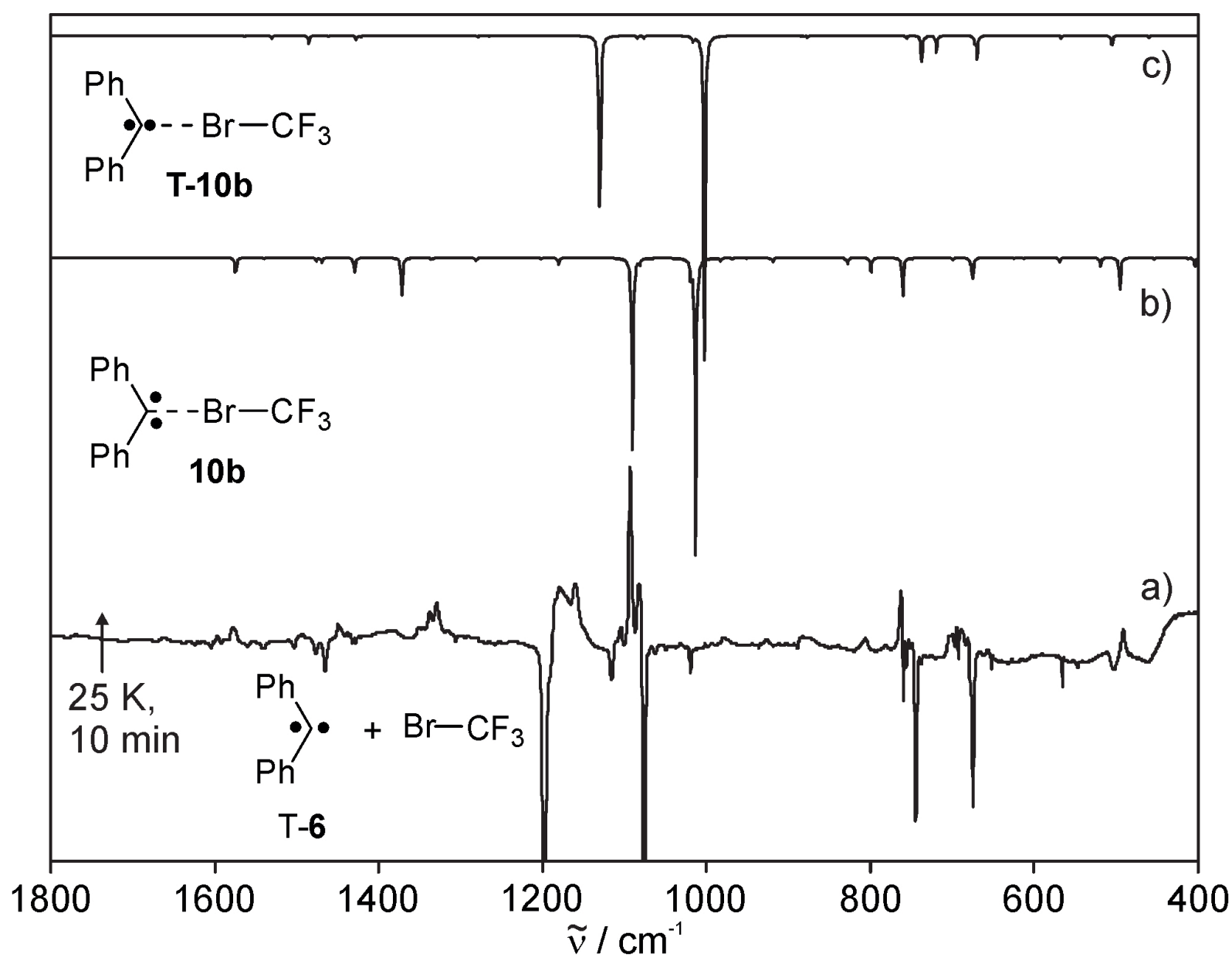

Figure S4. IR spectrum of the reaction of diphenylcarbene $\mathbf{6}$ with $\mathrm{BrCF}_{3}$. a) IR difference spectrum obtained upon annealing of an argon matrix containing triplet carbene 6 and $0.5 \%$ of $\mathrm{BrCF}_{3}$ to $25 \mathrm{~K}$ for $10 \mathrm{~min}$. b) Calculated IR spectrum of singlet complex 10b (B97-D3/def2-TZVP). c) Calculated IR spectrum of triplet complex T-10b (B97D3/def2-TZVP).

\begin{tabular}{|c|c|c|c|}
\hline \multicolumn{3}{|c|}{$\tilde{v} / \mathrm{cm}^{-1} \quad$ 10b } & $\tilde{v} / \mathrm{cm}^{-1} \quad 10 \mathbf{a}$ \\
\hline$\#$ & Calc. (Int.) $)^{a}$ & Exp. (Int.) $)^{b, c}$ & Exp. (Int.) ${ }^{a}$ \\
\hline \multirow[t]{2}{*}{20} & $494(13)$ & $492(8)$ & $504(4)$ \\
\hline & & & $529(3)$ \\
\hline 23 & $568(2)$ & $565(2)$ & $568(2)$ \\
\hline 27 & $674(7)$ & $675 / 680(4)$ & $679\left(^{d}\right)$ \\
\hline 31 & $760(13)$ & $762(18)$ & $764(11)$ \\
\hline 32 & $798(5)$ & $809(2)$ & $838(3)$ \\
\hline 44 & $1013(100)$ & $1093(71)$ & $1078(100)$ \\
\hline 49 & $1089(34)$ & \multirow{2}{*}{$1161(100)$} & \multirow{2}{*}{$1103(58)$} \\
\hline 50 & $1090(39)$ & & \\
\hline 54 & $1181(2)$ & $1198(2)$ & \\
\hline 60 & $1371(15)$ & $1329 / 1337(28)$ & $1338 / 1344(64)$ \\
\hline 61 & $1429(4)$ & \multirow{2}{*}{$1435(3)$} & \multirow{2}{*}{$1439(3)$} \\
\hline 62 & $1430(2)$ & & \\
\hline 63 & $1469(2)$ & \multirow{2}{*}{$1496(2)$} & \multirow{2}{*}{$1496(5)$} \\
\hline 64 & $1476(1)$ & & \\
\hline 67 & $1574(5)$ & $1576(9)$ & $1578(20)$ \\
\hline \multicolumn{4}{|c|}{$\begin{array}{l}{ }^{a} \text { Calculated at the B97D3/def2-TZVP level of theory }{ }^{b} \text { Measured in argon at } 3 \mathrm{~K} .{ }^{c} \text { Integrated } \\
\text { intensities refer to the difference spectrum. }{ }^{d} \text { Intensity not assigned due to overlapping of the } \\
\text { signal. }\end{array}$} \\
\hline
\end{tabular}




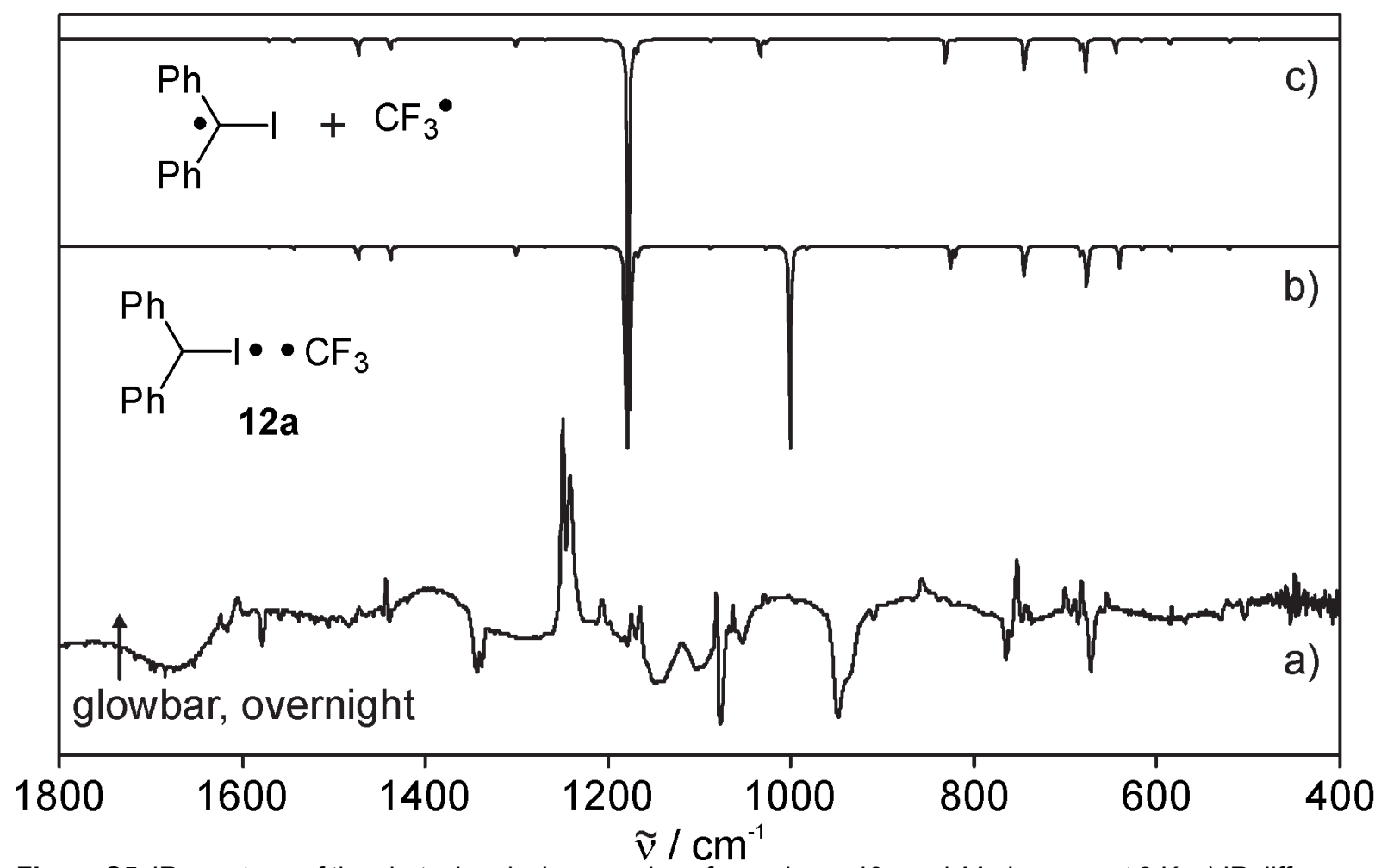

Figure S5. IR spectrum of the photochemical conversion of complexes 10a and 11a in argon at $3 \mathrm{~K}$. a) IR difference spectrum obtained upon keeping a matrix containing complexes 10a and 11a inside an IR spectrometer overnight. b) Calculated IR spectrum of radical pair 12a (B97-D3/def2-TZVP). c) Superposition of the calculated IR spectra of $\mathrm{Ph}_{2} \mathrm{Cl}$ and $\mathrm{CF}_{3}$ radical (B97-D3/def2-TZVP).

\begin{tabular}{|c|c|c|c|c|}
\hline \multirow[b]{2}{*}{ Mode } & \multicolumn{3}{|c|}{$\tilde{v} / \mathrm{cm}^{-1}$} & \multirow[b]{2}{*}{ Assignment } \\
\hline & $\begin{array}{l}\text { Exp. } \\
\left(I_{\text {rel }}\right)^{a}\end{array}$ & $\begin{array}{l}\text { Calc. gas phase } \\
\left(\left.\right|_{\text {rel }}\right)^{b}\end{array}$ & Calc. $\mathrm{QM} / \mathrm{MM}^{c}$ & \\
\hline 22 & $522(1)$ & $520(2)$ & 528 & C-H def. (out-of-plane) \\
\hline 23 & $583(1)$ & $584(3)$ & 579 & Skel. Vibr. \\
\hline 24 & $614(1)$ & $615(3)$ & 611 & Skel. Vibr. \\
\hline 26 & $654(4)$ & $641(16)$ & 629 & Skel. Vibr. \\
\hline 27 & 682(7) & $675(21)$ & 662 & $\mathrm{~F}_{3} \mathrm{C}-\mathrm{I}$ str. \\
\hline 28 & $689(3)$ & $677(20)$ & 684 & C-H def. (out-of-plane) \\
\hline 29 & $700(7)$ & $683(6)$ & 691 & C-H def. (out-of-plane) \\
\hline 31 & $752(19)$ & $745(18)$ & 749 & C-H def. (out-of-plane) \\
\hline 34 & $857(6)$ & $824(13)$ & 827 & C-I str. \\
\hline 46 & \multirow{2}{*}{$1082(12)$} & $1027(2)$ & 1013 & C-H def. (in-plane) \\
\hline 47 & & $1088(2)$ & 1071 & $\mathrm{C}-\mathrm{H}$ def. (in-plane) \\
\hline 50 & $1206(6)$ & $1167(5)$ & 1117 & $\begin{array}{l}\text { C-C-C sym. str. } \\
\text { (carbene) }\end{array}$ \\
\hline 52 & 1242(100) & $1176(100)$ & 1167 & C-F 3 asym. str. \\
\hline 53 & $1249(90)$ & $1181(90)$ & 1170 & C-F3 asym. str. \\
\hline 62 & $1443(6)$ & $1438(9)$ & 1425 & $\mathrm{C}=\mathrm{C}$ str. Ring \\
\hline 63 & $1473(2)$ & $1473(8)$ & 1475 & $\mathrm{C}=\mathrm{C}$ str. Ring \\
\hline \multicolumn{5}{|c|}{$\begin{array}{l}{ }^{a} \text { Measured in argon at } 3 \mathrm{~K} \text {. Integrated intensities refer to the difference spectrum. }{ }^{b} \text { Calculated at the } \\
\text { B97D3/def2-TZVP level of theory. }{ }^{c} \text { Calculated at the B97D3/dfe2-TZVP//CHARMM level of theory in an Ar } \\
\text { matrix. }\end{array}$} \\
\hline
\end{tabular}




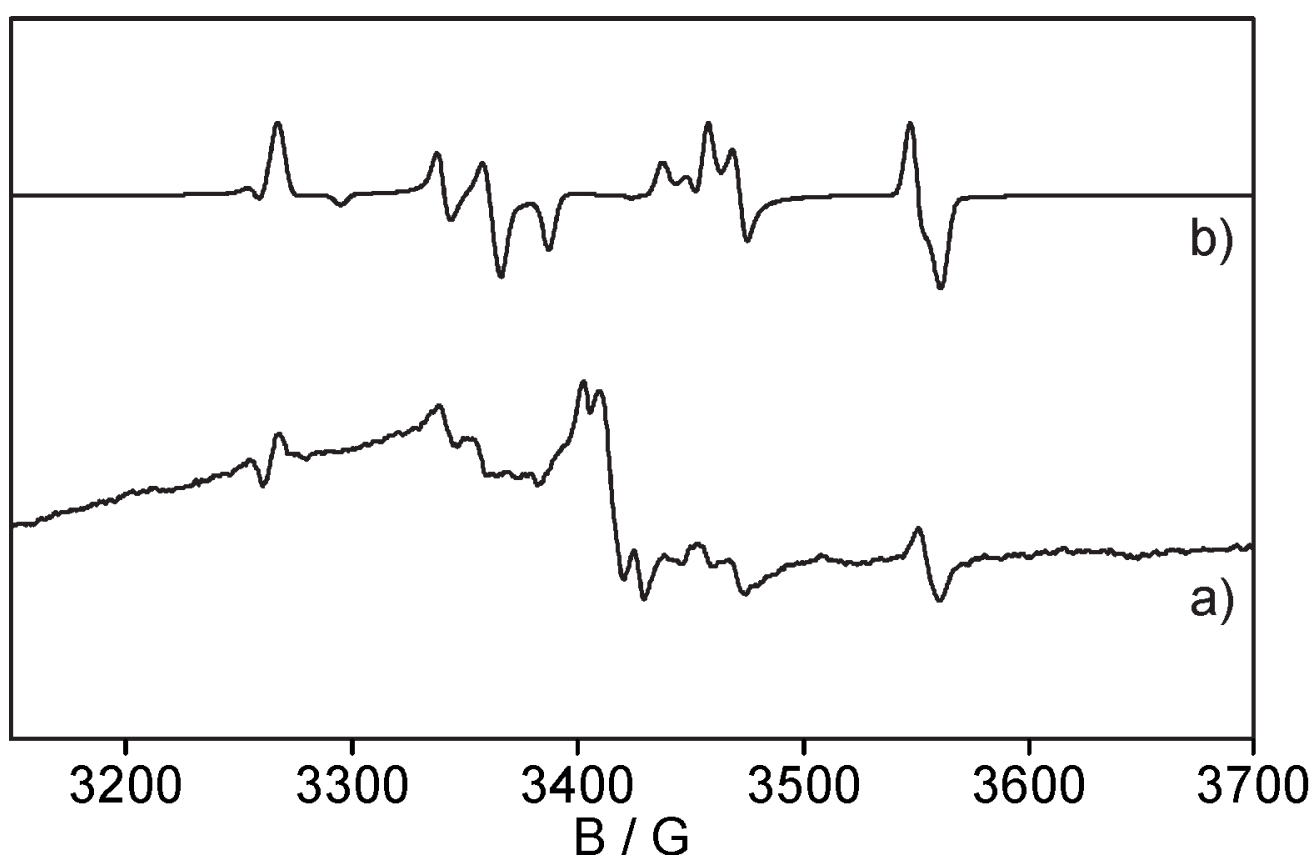

Figure S6. EPR spectrum of $\mathrm{CF}_{3}$ radicals. a) EPR spectrum obtained upon irradiation (450 $\mathrm{nm}$ ) of an annealed matrix containing diphenylcarbene 6 and $1 \%$ of ICF 3 . b) Simulated EPR spectrum $(\mu=9.575 \mathrm{GHz}, \mathrm{g} 1=2.0023 \mathrm{~g} 2$ $=1.994 \mathrm{~g} 3=2.004 \mathrm{~A} 1=823 \mathrm{MHz} \mathrm{A} 2=235 \mathrm{MHz} \mathrm{A} 3=270 \mathrm{MHz})$

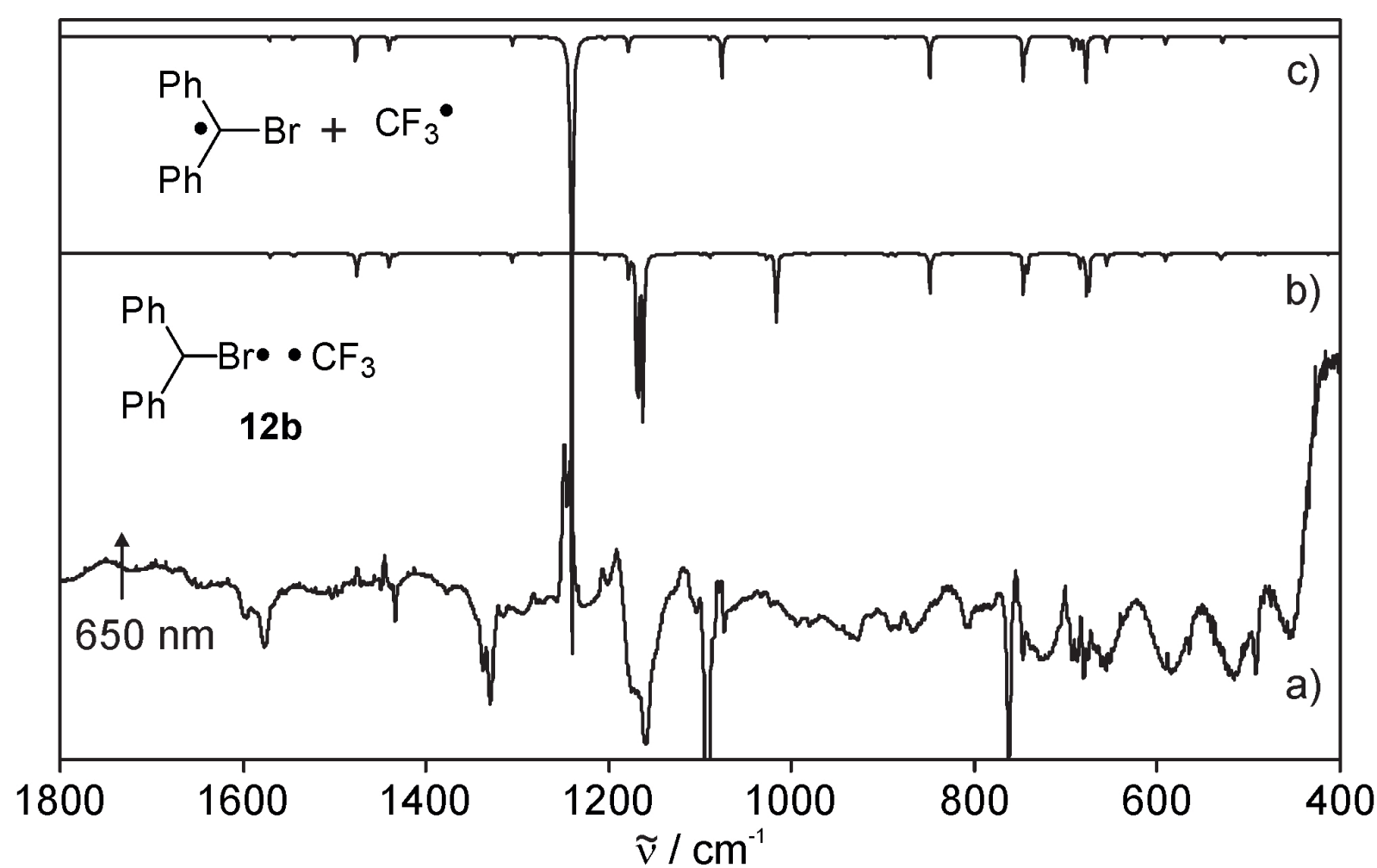

Figure S7. IR spectrum of the photochemical conversion of complexes $10 \mathrm{~b}$ in argon at $3 \mathrm{~K}$. a) IR difference spectrum obtained upon irradiation of complex $10 \mathrm{~b}$ with $650 \mathrm{~nm}$ light. b) Calculated IR spectrum of radical pair 12b (B97-D3/def2-TZVP). c) Superposition of the calculated IR spectra of $\mathrm{Ph}_{2} \mathrm{CBr}$ and $\mathrm{CF}_{3}$ radical (B97-D3/def2-TZVP). 


\begin{tabular}{|c|c|c|c|c|}
\hline \multirow[b]{2}{*}{ Mode } & \multicolumn{4}{|c|}{$\tilde{v} / \mathrm{cm}^{-1}$} \\
\hline & $\begin{array}{l}\text { Exp. } \\
\left(\text { I }_{\text {rel }}\right)^{a}\end{array}$ & $\begin{array}{l}\text { Calc. gas phase } \\
\left(\left.\right|_{\text {rel }}\right)^{b}\end{array}$ & Calc. $\mathrm{CF}_{3}$ radical $\left(I_{\text {rel }}\right)$ & Calc. $\left(I_{\text {rel }}\right)^{c}$ \\
\hline 22 & $528(2)$ & $527(4)$ & & $528(1)$ \\
\hline 23 & $588(3)$ & $592(5)$ & & $591(2)$ \\
\hline 24 & $611(1)$ & $618(1)$ & & $617(0)$ \\
\hline 26 & $641(3)$ & $659(7)$ & & $655(3)$ \\
\hline 27 & $683(11)$ & $674(37)$ & $678(1)$ & \\
\hline 28 & $689(6)$ & $675(1)$ & & $678(8)$ \\
\hline 29 & $700(8)$ & $681(10)$ & & $685(2)$ \\
\hline 31 & \multirow{2}{*}{$754(23)$} & $740(9)$ & & \multirow{2}{*}{$743 / 746(9)$} \\
\hline 32 & & $745(20)$ & & \\
\hline 34 & $876(5)$ & $855(20)$ & & $848(8)$ \\
\hline 44 & $1082(22)$ & $1021(44)$ & $1033(5)$ & \\
\hline 51 & $1243(100)$ & $1166(100)$ & \multirow{2}{*}{$1178 / 1178(100)$} & \\
\hline 52 & $1249(88)$ & $1170(98)$ & & \\
\hline 62 & $1445(4)$ & $1446(9)$ & & $1440(3)$ \\
\hline $63 / 64$ & $1475(7)$ & $1478 / 1479(16)$ & & $1477 / 1478(4)$ \\
\hline
\end{tabular}




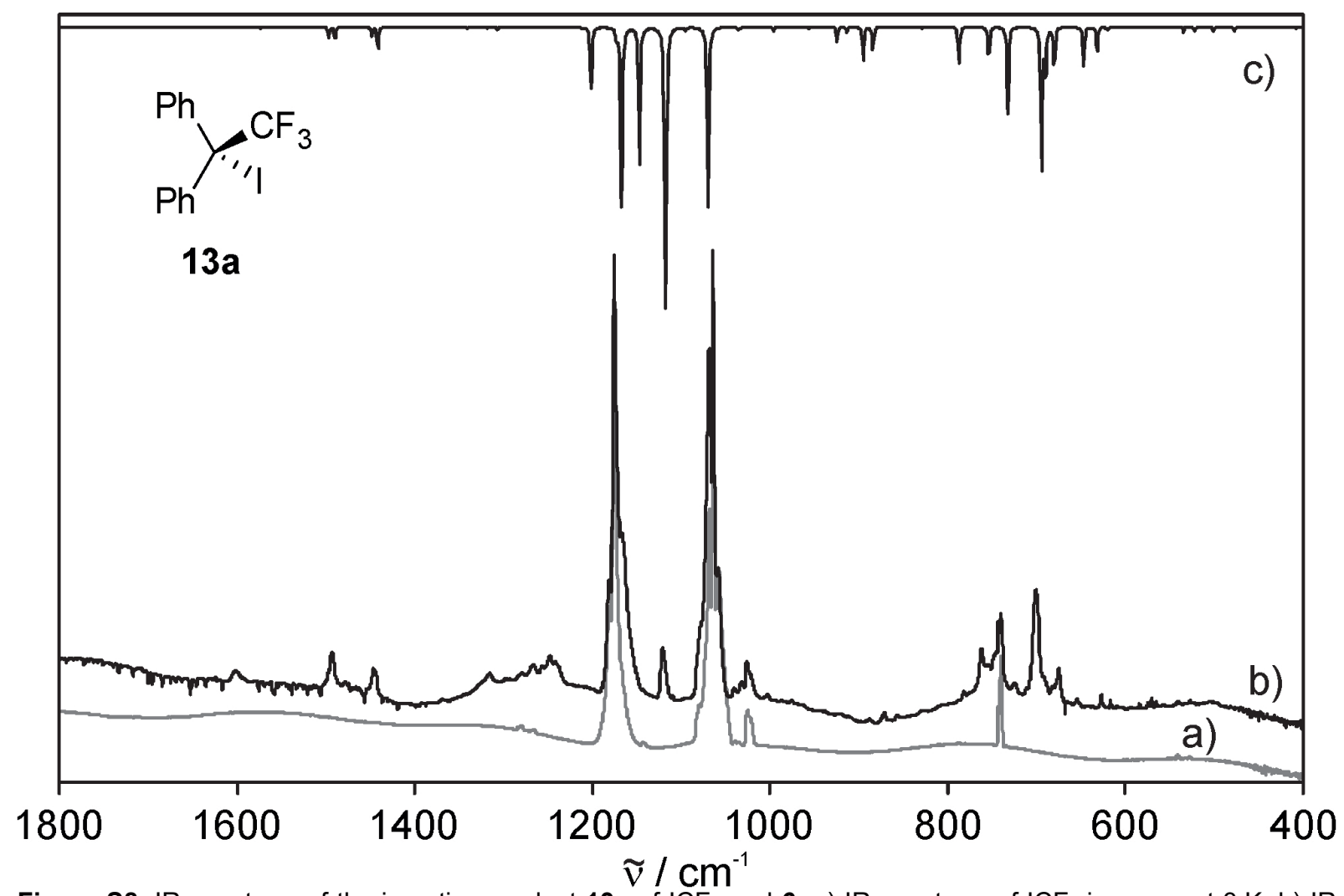

Figure S8. IR spectrum of the insertion product $13 a$ of $\mathrm{ICF}_{3}$ and 6 . a) IR spectrum of ICF 3 in argon at $3 \mathrm{~K}$. b) IR spectrum obtained after $450 \mathrm{~nm}$ irradiation of the annealed matrix. c) Calculated IR spectrum of 13a (B97-D3/def2TZVP).

Table S6. Experimental (Ar, $3 \mathrm{~K}$ ) and calculated (B97-D3/def2-TZVP) frequencies of 13a.

\begin{tabular}{|c|c|c|}
\hline \multirow[b]{2}{*}{ Mode } & \multicolumn{2}{|c|}{$\tilde{v} / \mathrm{cm}^{-1}$} \\
\hline & $\begin{array}{l}\text { Exp. } \\
\text { (Irel) }^{a}\end{array}$ & $\begin{array}{l}\text { Calc. gas phase } \\
\left(\left.\right|_{\text {rel }}\right)^{b}\end{array}$ \\
\hline 25 & $654(5)$ & $646(13)$ \\
\hline 26 & $674(15)$ & $680(12)$ \\
\hline 27 & \multirow{2}{*}{$700(100)$} & $690(15)$ \\
\hline 28 & & 694(41) \\
\hline 29 & $740(31)$ & $732(25)$ \\
\hline 30 & $761(14)$ & $754(9)$ \\
\hline 31 & $825(6)$ & $787(11)$ \\
\hline 46 & $\mathrm{c}$ & $1070(61)$ \\
\hline 49 & $\mathrm{c}$ & $1117(100)$ \\
\hline 50 & $\mathrm{c}$ & $1147(42)$ \\
\hline 51 & $\mathrm{c}$ & $1167(56)$ \\
\hline 54 & $\begin{array}{c}\mathrm{c} \\
\mathrm{C}\end{array}$ & 1201(17) \\
\hline 61 & \multirow{2}{*}{$1446(12)$} & $1441(7)$ \\
\hline 62 & & $1448(3)$ \\
\hline 63 & \multirow{2}{*}{ 1493(13) } & $1490(4)$ \\
\hline 64 & & $1497(4)$ \\
\hline
\end{tabular}




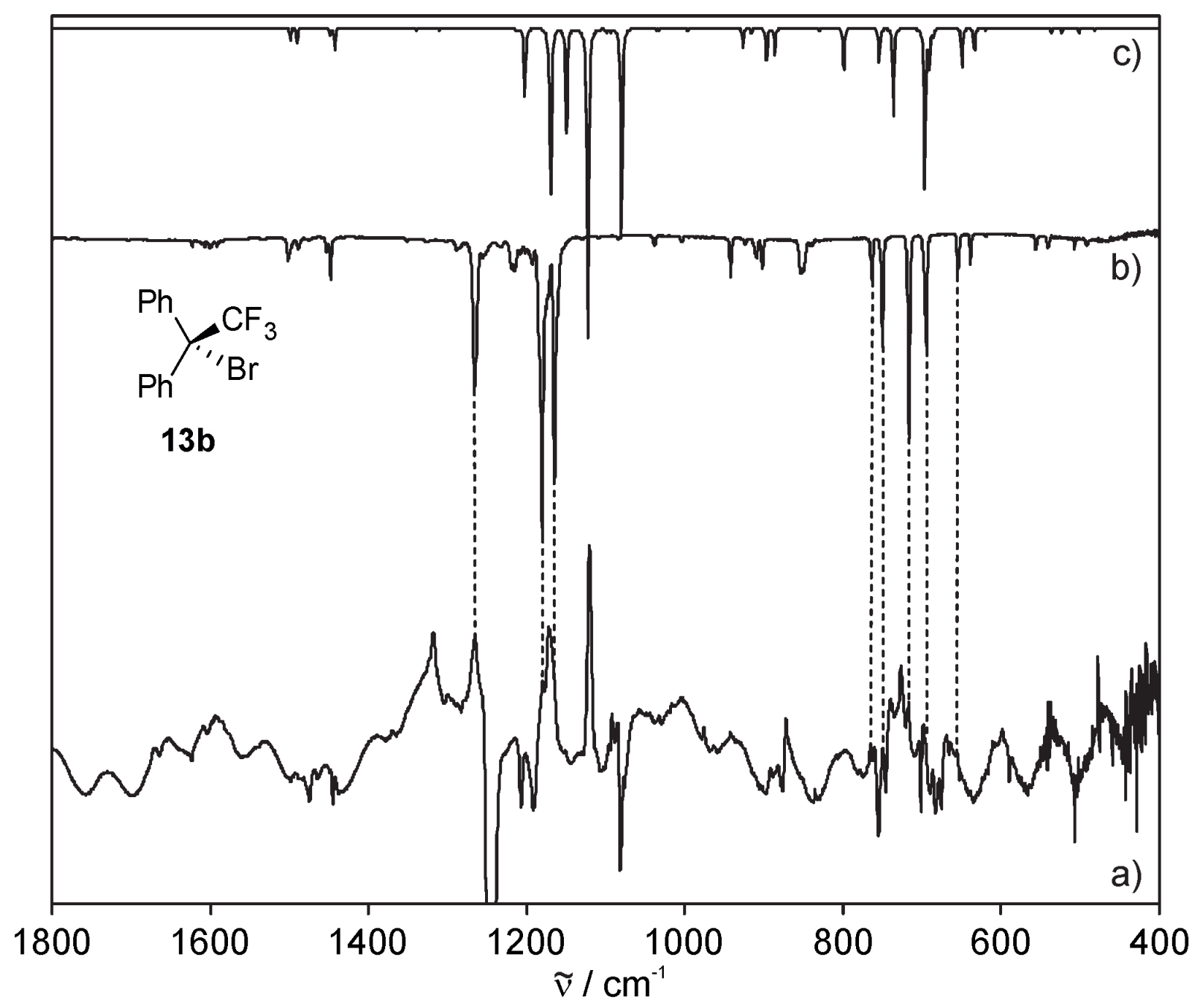

Figure S9. IR spectrum of the insertion product $13 \mathrm{~b}$ of $\mathrm{BrCF}_{3}$ and 6 . a) IR difference obtained on annealing of an argon matrix containing 12b. b) IR spectrum of $\mathbf{1 3 b}$ in argon at $10 \mathrm{~K}$. (Trifluoromethyl)diphenylmethyl bromide 13b was prepared according to literature procedure: Ohwada, T.; Shudo, K. J. Am. Chem. Soc. 1988, 110, 1862. c) Calculated IR spectrum of 13b (B97-D3/def2-TZVP). 
Table S7. Experimental ( $\mathrm{Ar}, 10 \mathrm{~K})$ and calculated (B97-D3/def2-TZVP) frequencies of 13b.

\begin{tabular}{|c|c|c|}
\hline \multirow[b]{2}{*}{ Mode } & \multicolumn{2}{|c|}{$\tilde{v} / \mathrm{cm}^{-1}$} \\
\hline & $\begin{array}{l}\text { Exp. } \\
\left(I_{\text {rel }}\right)^{a}\end{array}$ & $\begin{array}{l}\text { Calc. gas phase } \\
\left(\left.\right|_{\text {rel| }} ^{b}\right.\end{array}$ \\
\hline 18 & $491(1)$ & $482(1)$ \\
\hline 19 & $507(1)$ & $501(1)$ \\
\hline 20 & $540(2)$ & $523(1)$ \\
\hline 21 & $556(2)$ & $536(1)$ \\
\hline 22 & $619(0.3)$ & $619(0.5)$ \\
\hline 24 & $639(4)$ & $633(7)$ \\
\hline 25 & $655(7)$ & $649(11)$ \\
\hline 27 & $694(24)$ & $691(12)$ \\
\hline 28 & 717 (35) & $696(43)$ \\
\hline 29 & $749(18)$ & $736(24)$ \\
\hline 30 & $763(7)$ & $754(9)$ \\
\hline 31 & 853 (15) & $798(13)$ \\
\hline 34 & $902(5)$ & $886(7)$ \\
\hline 35 & $909(5)$ & 897 (11) \\
\hline 36 & $924(1)$ & $915(2)$ \\
\hline 37 & $942(5)$ & $926(5)$ \\
\hline 42 & \multirow{2}{*}{1005 (1) } & $996(1)$ \\
\hline 43 & & $997(1)$ \\
\hline 44 & \multirow{2}{*}{$1038(2)$} & $1032(1)$ \\
\hline 45 & & $1036(1)$ \\
\hline 46 & $1165(62)$ & $1080(61)$ \\
\hline 49 & $1181(100)$ & $1122(100)$ \\
\hline 50 & $1215(14)$ & $1150(32)$ \\
\hline 51 & $1233(5)$ & $1169(46)$ \\
\hline 54 & \multirow{2}{*}{$1266(50)$} & $1201(3)$ \\
\hline 55 & & $1202(20)$ \\
\hline 57 & $1289(2)$ & $1310(1)$ \\
\hline 58 & $1302(0.4)$ & $1320(0.4)$ \\
\hline 59 & $1327(1)$ & $1339(1)$ \\
\hline 60 & $1352(0.5)$ & $1355(0.2)$ \\
\hline 61 & $1449(6)$ & $1443(6)$ \\
\hline 62 & $1453(2)$ & $1448(2)$ \\
\hline 63 & $1489(3)$ & $1490(4)$ \\
\hline 64 & $1503(6)$ & $1499(3)$ \\
\hline 71 & \multirow{2}{*}{3046 (3) } & $3120(5)$ \\
\hline 72 & & $3120(5)$ \\
\hline 73 & \multirow{2}{*}{$3075(8)$} & $3130(13)$ \\
\hline 74 & & $3132(11)$ \\
\hline 75 & 3098 (1) & $3138(4)$ \\
\hline 76 & $3109(1)$ & $3147(3)$ \\
\hline 78 & $3171(0.2)$ & $3182(1)$ \\
\hline
\end{tabular}




\section{Computational Results}

\begin{tabular}{|c|c|c|c|}
\hline \multirow[b]{2}{*}{ Complexes } & \multicolumn{3}{|c|}{ B97-D3/def2-TZVP } \\
\hline & $\Delta \mathrm{Es}$ & $\Delta \mathrm{EsC}_{(\mathrm{BSSE})}$ & $\begin{array}{c}\mathrm{Er} \\
\text { (to the triplet state) }\end{array}$ \\
\hline $\mathrm{S}-6 \ldots \mathrm{HOCH}_{3}$ & -11.6 & -10.8 & 1.2 \\
\hline $\mathrm{T}-6 \ldots \mathrm{HOCH}_{3}$ & -6.1 & -5.9 & 0.0 \\
\hline S-10a & -16.1 & -15.8 & -3.7 \\
\hline T-10a & -6.1 & -6.0 & 0.0 \\
\hline S-10b & -11.0 & -10.7 & -0.5 \\
\hline$T-10 b$ & -4.2 & -4.1 & 0.0 \\
\hline
\end{tabular}

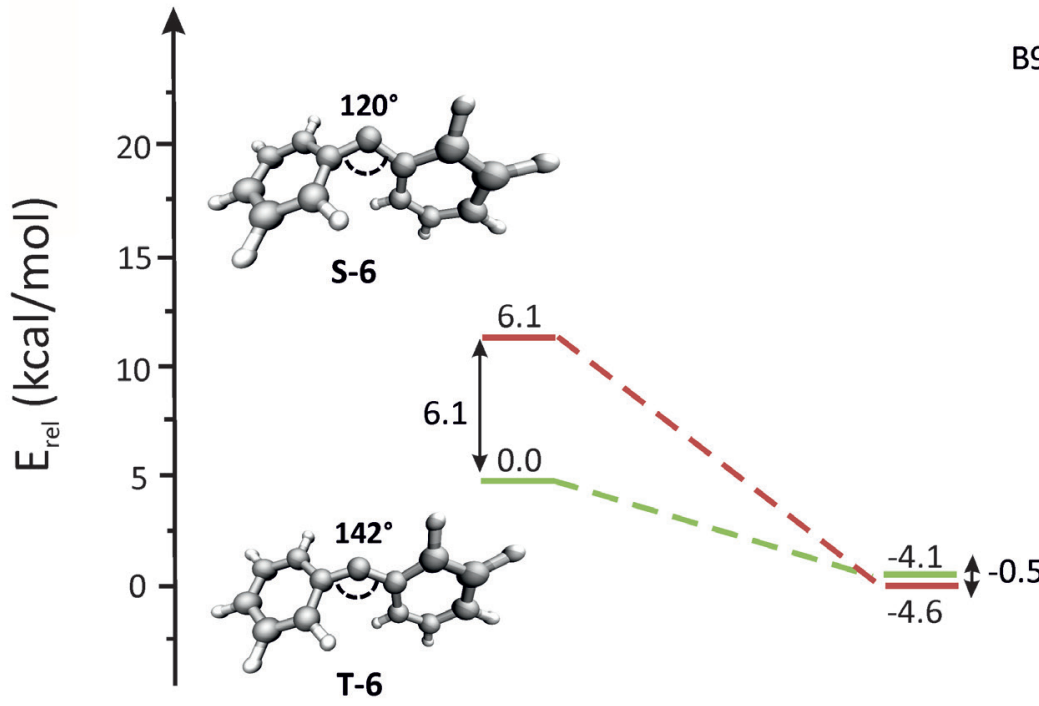

Fig. S10 Relative energies (including BSSE correction) and relevant geometric parameters of singlet and triplet $\mathrm{DPC}$ and the corresponding halogen bonded complexes with $\mathrm{CF}_{3} \mathrm{Br}$ in the gas phase computed at the B97-D3/def2TZVP level of theory.

\section{Natural Bond Orbital (NBO) analysis}

The main NBO interactions involved in both the H-bonded and the type-I X-bonded complexes of S6 are shown in Table S9. In both cases the main interaction is established between the lone pair of the carbene center $(\mathrm{LP}(\mathrm{C}:))$ and the anti-bonding orbital of the other molecule, $\mathrm{BD}^{*}(\mathrm{I}-\mathrm{C})$ for $\mathrm{CF}_{3} \mathrm{I}$ and $\mathrm{BD}^{*}(\mathrm{H}-\mathrm{O})$ for the methanol complex. For the $\mathrm{X}$-bonded complex an additional, weaker interaction can be identified, involving a back-donation from the lone pair of the iodine atom (LP3(I)) towards the empty $\mathrm{p}$ orbital on the carbene center $\left(\mathrm{LP}^{*}(\mathrm{C}:)\right)$. This interaction cannot be found in the $\mathrm{H}$ bonded complex, since the $\mathrm{H}$ atom lacks the lone pair to engage in this back-donation.

\begin{tabular}{|c|c|c|c|c|}
\hline Complex & \multicolumn{4}{|c|}{ Orbital interactions } \\
\hline \multirow{3}{*}{ S-10a } & Donor(i)-Acceptor(j) & $\mathrm{E}(\mathrm{kcal} / \mathrm{mol})$ & $E(j)-E(i)$ (a. u.) & $F(i, j)(a$. u. $)$ \\
\hline & $\mathrm{LP}(\mathrm{C}:)-\mathrm{BD}^{*}(\mathrm{I}-\mathrm{C})$ & 53.69 & 0.21 & 0.096 \\
\hline & LP3(I)-LP*(C:) & 5.60 & 0.10 & 0.024 \\
\hline $\mathrm{S}-6 \ldots \mathrm{HOCH}_{3}$ & $\mathrm{LP}(\mathrm{C}:)-\mathrm{BD}^{*}(\mathrm{H}-\mathrm{O})$ & 57.28 & 0.34 & 0.133 \\
\hline
\end{tabular}


The main NBO interactions for complexes S-10a and 11a are shown in Table S10. In complex 11a, the main directional interaction is established between the lone pair at the carbon atom of $\mathrm{CF}_{3}$ and the anti-bonding orbital on the C-I bond ( $\left.\mathrm{LP} 1\left(\mathrm{CF}_{3}\right)-\mathrm{BD}^{*}(\mathrm{C}-\mathrm{I})\right)$ and it is diminished in comparison with the interaction in complex S-10a. This is related to the loss of linearity of the halogen bond, which allows a back-donation interaction from the lone pair of the iodine atom towards the same lone pair orbital on $\mathrm{CF}_{3}$. This interaction helps to compensate the weaker primary interaction (with respect to the type-I complex), explaining the near degeneracy of both types of complexes.

\begin{tabular}{|c|c|c|c|c|}
\hline Complex & & Orbital in & ons & \\
\hline & Donor(i)-Acceptor(j) & $\mathrm{E}(\mathrm{kcal} / \mathrm{mol})$ & $E(j)-E(i)$ (a. u.) & $F(i, j)$ (a. u.) \\
\hline \multirow{2}{*}{$S-10 a$} & LP(C:)-BD*(I-C) & 53.69 & 0.21 & 0.096 \\
\hline & LP3(I)-LP*(C:) & 5.60 & 0.10 & 0.024 \\
\hline \multirow{2}{*}{$11 a$} & $\mathrm{LP} 1\left(\mathrm{CF}_{3}\right)-\mathrm{BD}^{*}(\mathrm{C}-\mathrm{I})$ & 35.53 & 0.19 & 0.083 \\
\hline & LP3(I)-LP1 $\left(\mathrm{CF}_{3}\right)$ & 25.21 & 0.11 & 0.063 \\
\hline
\end{tabular}

Fig. S11 The HOMO and HOMO-2 orbitals of the type-I complex S-10a illustrating the main directional
interaction and the back-donation from the iodine atom. (B97-D3/def2-TZVP)
HOMO

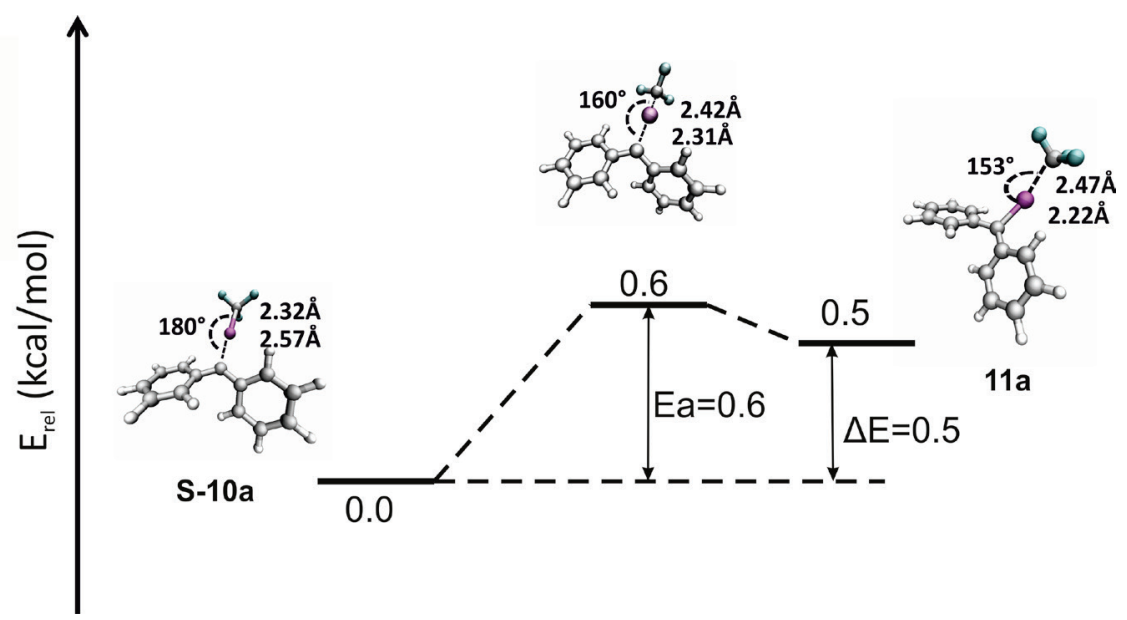

Fig. S12 Reaction path for the interconversion of the singlet complexes S-10a and 11a (B97-D3/def2-TZVP). 


\section{CASSCF calculations}

\section{Active space:}

From a general perspective, it would be desirable to define an active space that includes the $\pi$ and $\pi^{*}$ orbitals from the two phenyl rings, the pi and sigma orbitals at the carbene center, and the C-I bonding and anti-bonding orbitals (without considering the lone pairs on the halogen atoms). The resulting active space with 16 electrons in 16 orbitals is too large to be practical. To limit the computational cost, we decided to include only 8 electrons and 8 orbitals in the active space. This selection was performed iteratively as follows.

The active space ( 8 electrons and 8 orbitals) was chosen differently for the singlet and triplet systems. The initial selection of orbitals was based on chemical intuition. The active space orbitals are shown in Figure S13. The carbene center has two nonbonded orbitals, $\sigma_{\mathrm{C}}$ and $\pi_{\mathrm{C}}$. In addition to these two orbitals, the $\pi$ and $\pi^{*}$ orbitals from the phenyl substituent were included. In general, halogen bonds are formed by the overlap of a $\sigma$-hole (in this case $\sigma_{I}^{*}$ ) with electron-rich centers. Hence, the $\sigma_{I}^{*}$ and $\sigma_{I}$ orbitals were also considered for the active space. For S-10a, among the variations tested, the fully occupied $\sigma_{\mathrm{C}}$ and unoccupied $\pi_{\mathrm{C}}$ configuration gives rise to low energy states (see below). Hence, we used this configuration. The $\sigma_{\mathrm{I}}^{*}$ and $\sigma_{\mathrm{I}}$ orbitals were included as they are important for X-bond formation. In the case of T-10a, the $\sigma_{\mathrm{C}}$ and $\pi_{\mathrm{C}}$ orbitals are singly occupied and therefore included in the active space. The singly occupied $\pi_{\mathrm{C}}$ might favorably interact with the $\pi$-system of phenyl rings. Test calculations indicated that the inclusion of $\sigma_{\mathrm{I}}{ }^{*}$ and $\sigma_{\mathrm{I}}$ orbitals is not crucial for T-10a and therefore they are not part of the active space.

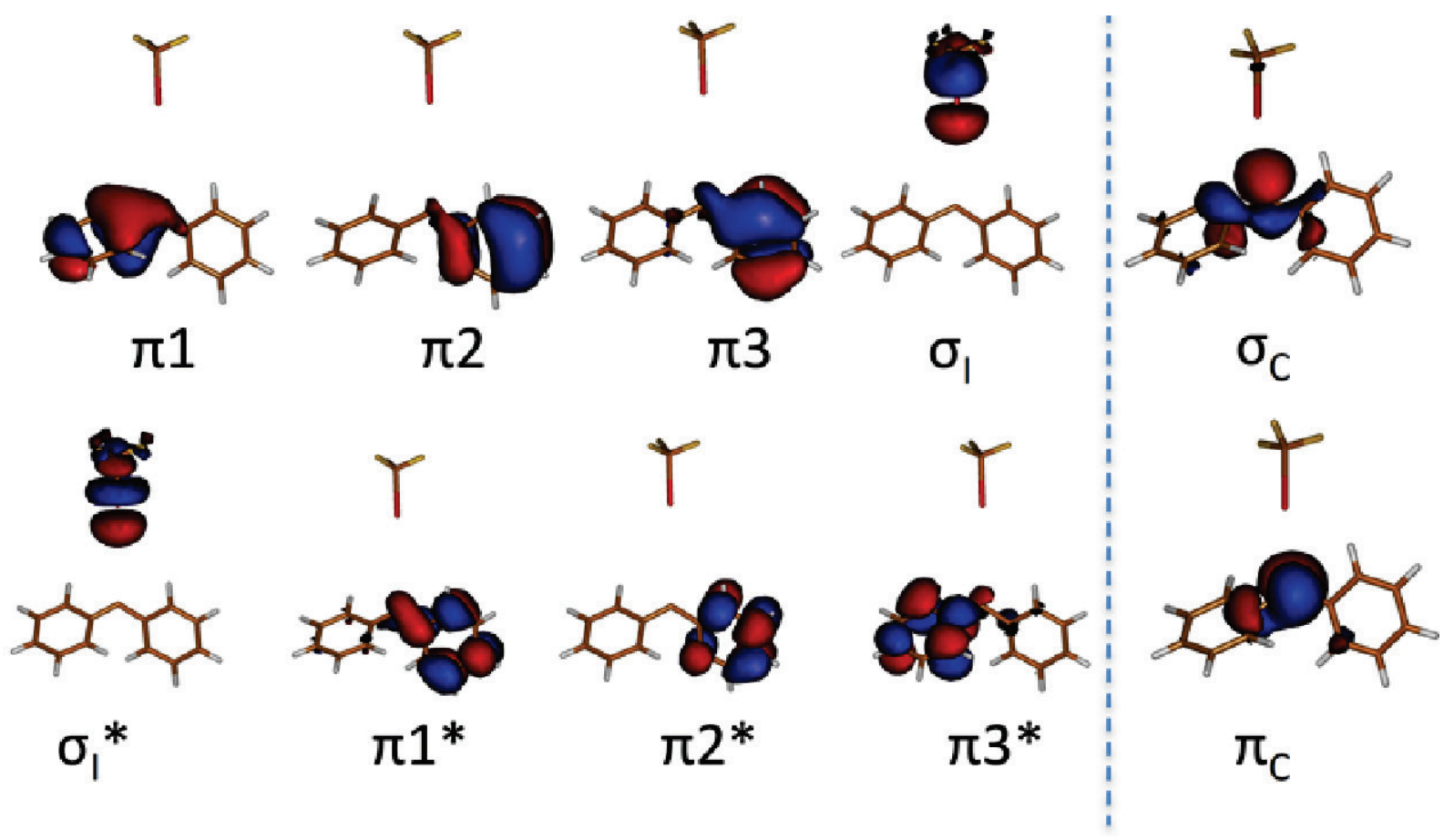

Fig. S13 Active space (8 electrons and 8 orbitals) used in the CASSCF MP2 calculations of the DPC-CF 1 complexes. Bonding and anti-bonding orbitals of the $\mathrm{C}-\mathrm{I}$ bond in $\mathrm{CF}_{3} \mathrm{I}$ are denoted as $\sigma_{1}$ and $\sigma_{1}{ }^{*}$, respectively. The $\sigma$ and $\pi$ orbitals at the carbene center are denoted as $\sigma_{c}$ and $\pi_{c}$, respectively. For the S-10a calculations, the $\sigma_{C}$ and $\pi c$ orbitals were not included in the active space. For the T-10a calculations, $\sigma_{l}$ and $\sigma_{1}{ }^{*}$ were not included in the active space. 


\section{Multistate CASSCF calculations}

We performed state-averaged multistate CASSCF (MS-CASSCF) calculations involving two states to calculate the vertical excitation energies for complex 10a and 11a. Single point MS-CASSCF calculations were performed for DFT geometries of 10a and $11 \mathbf{a}$ using an active space of 12 electrons and 12 orbitals. The active space included the ten orbitals shown in Fig. S13, in addition one $\pi$ and one $\pi^{*}$ orbital were also included (not shown). In the case of 10a, the $\sigma_{C}{ }^{2} \pi_{C}{ }^{0}>\sigma_{C}{ }^{1} \pi_{C}{ }^{1}$ transition (at 944 $\mathrm{nm}$ ) was dominant with the $\sigma_{\mathrm{C}}{ }^{2} \pi_{\mathrm{C}}{ }^{0}$ configuration having highest CI coefficient at $\mathrm{S}_{0}$ state and $\sigma_{\mathrm{C}}{ }^{1} \pi_{\mathrm{C}}{ }^{1}$ at $S_{1}$ state. In the case of $11 \mathrm{a}$, the $S_{0}$ and $S_{1}$ states were found to have almost equal populations of $\sigma_{\mathrm{C}}{ }^{2} \pi_{\mathrm{C}}{ }^{0}$ and $\sigma_{C}{ }^{1} \pi_{C}{ }^{1}$. These transitions $\left(\sigma_{C}^{2} \pi_{C}{ }^{0}->\sigma_{C}{ }^{1} \pi_{C}{ }^{1}\right.$ and $\left.\sigma_{C}{ }^{1} \pi_{C}{ }^{1}->\sigma_{C}{ }^{2} \pi_{C}{ }^{0}\right)$ occur at $784 \mathrm{~nm}$.

\section{CASMP2 results with $\sigma_{\mathrm{C}}$ and $\pi_{\mathrm{C}}$ orbitals}

As mentioned above, we did not include the $\sigma_{\mathrm{C}}$ and $\pi_{\mathrm{C}}$ orbitals (centered on carbene) in our ground state CASMP2 calculations of S-10a. Nevertheless, we ran a separate set of calculations with these two orbitals in the active space to compare the results. This way, the active space for these calculations consisted of the $\sigma_{\mathrm{C}}, \pi_{\mathrm{C}}, \pi_{1}, \pi_{1}{ }^{*}, \pi_{2}, \pi_{2}{ }^{*}, \sigma_{\mathrm{I}}$ and $\sigma_{\mathrm{I}}{ }^{*}$ orbitals shown in Figure S13. The resulting potential energy scan (as a function of the C-I distance) at the CASMP2//DFT level is shown in Figure S14A. The comparison to the results shown in Figure $7 \mathrm{~A}$ indicates that the inclusion of $\sigma_{\mathrm{C}}$ and $\pi_{\mathrm{C}}$ orbitals raises the energy of S-10a by $2.5 \mathrm{kcal} / \mathrm{mol}$. In addition, with the inclusion of $\sigma_{\mathrm{C}}$ and $\pi_{\mathrm{C}}$ orbitals, the minimum in the PES corresponding to 11 a cannot be observed, not even in the $2 \mathrm{D}$-scan (Figure $7 \mathrm{~B}$ and Figure S14B). 
A

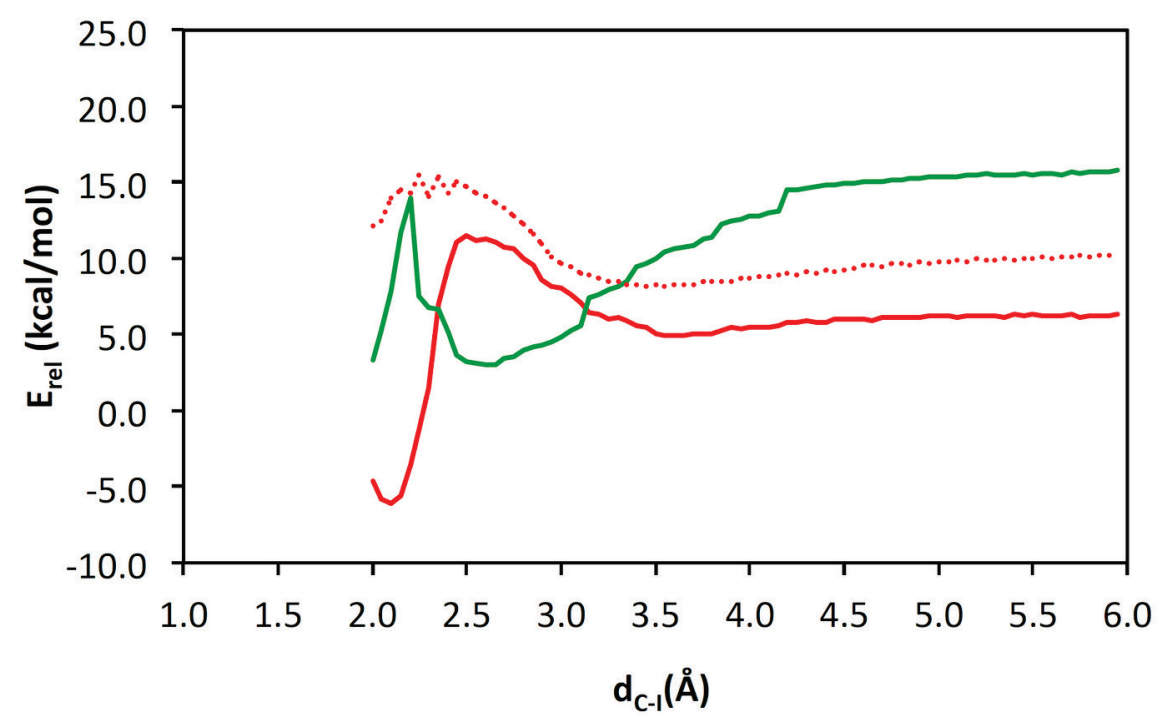

B

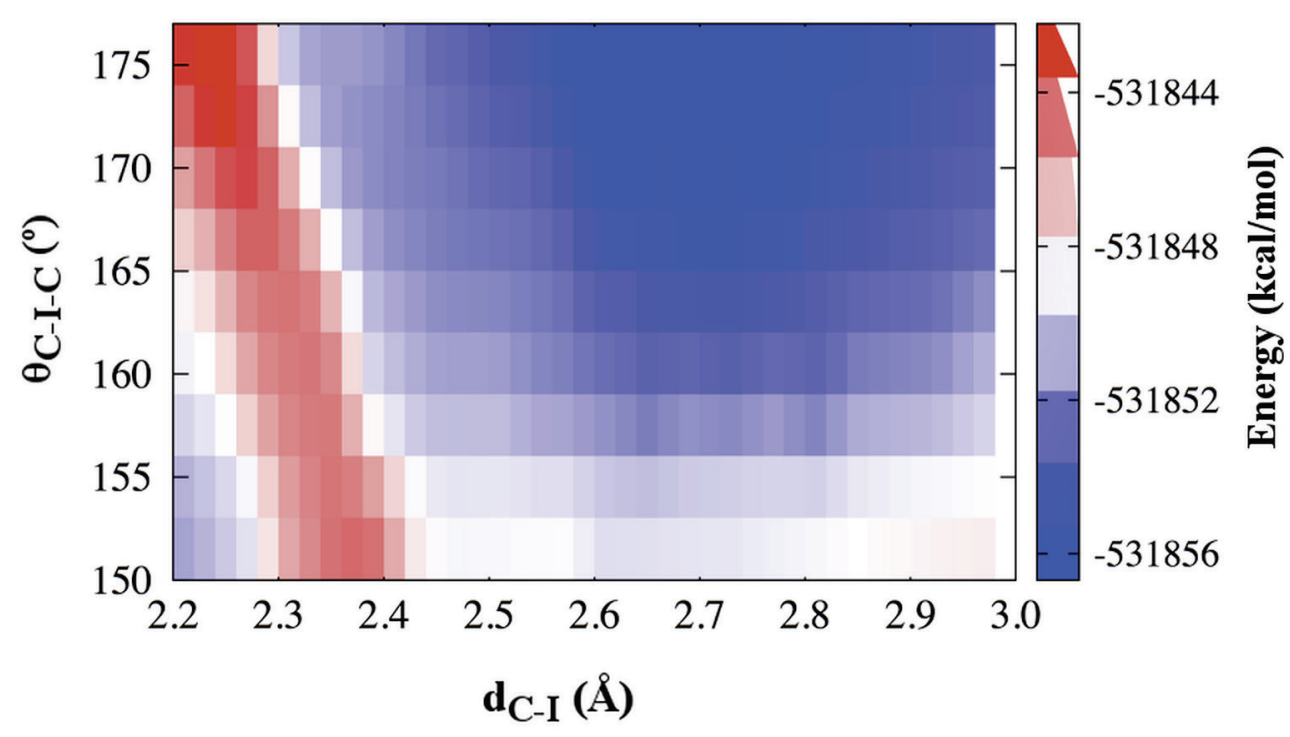

Fig. S14 A) Crossing point between singlet and triplet potential energy surfaces of 10a. The potential energy profiles were obtained by performing constrained optimizations along the $\mathrm{C}-\mathrm{I}$ distance. Potential energies are relative to that of S-10a (as shown in Figure 7B). B) 2D-potential energy scan, using the halogen bonding distance and angle as reaction coordinates, is shown as color-coded heat map. Potential energy surfaces were constructed by single point CASMP2 calculations on the DFT-optimized geometries. A different active space that includes $\sigma_{c}$ and $\pi_{C}$ orbitals was used for these calculations (see text). 


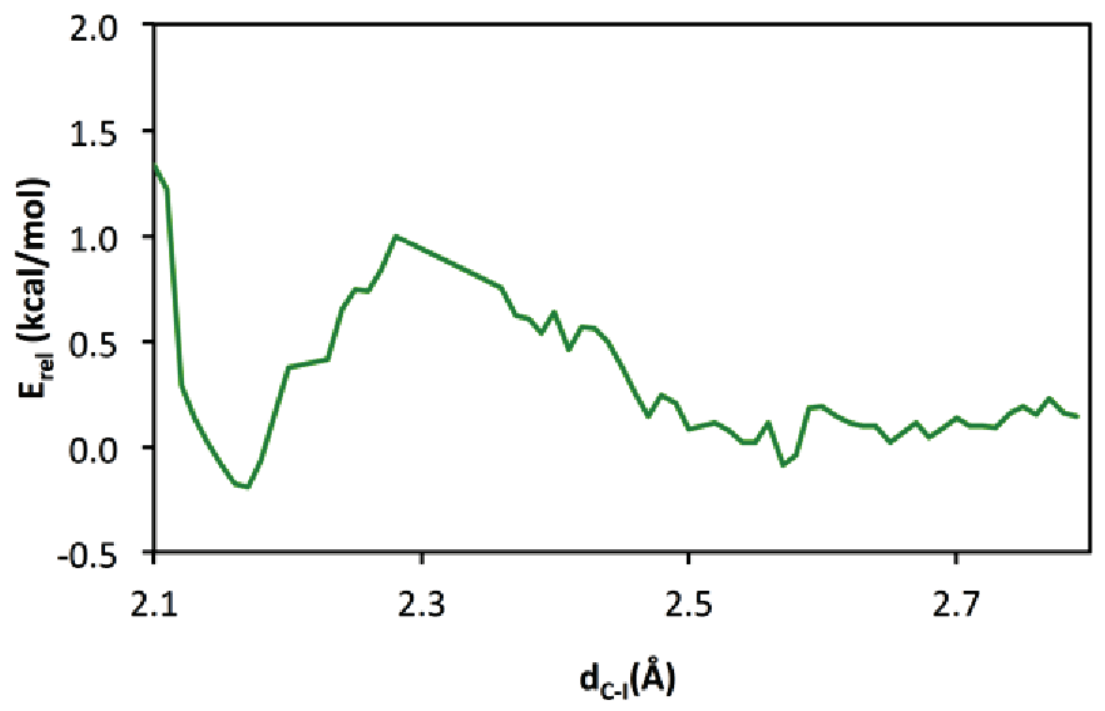

Fig. S15 The potential energy profile obtained by performing constrained optimizations along the C-I distance ( 2.1 - $2.8 \AA$, window of $0.01 \AA$ ) provides an estimate of the energy difference between S-10a and 11a. 


\section{Cartesian coordinates of optimized structures}

\begin{tabular}{|c|c|c|c|}
\hline Atomic Symbol & $\mathrm{x}$ & $\mathrm{y}$ & $\mathrm{z}$ \\
\hline $\mathrm{C}$ & -0.774 & 2.681 & -1.245 \\
\hline C & -0.721 & 1.430 & -0.641 \\
\hline C & 0.000 & 1.233 & 0.577 \\
\hline $\mathrm{C}$ & 0.678 & 2.358 & 1.133 \\
\hline C & 0.690 & 3.580 & 0.476 \\
\hline C & -0.053 & 3.753 & -0.704 \\
\hline $\mathrm{H}$ & -1.358 & 2.824 & -2.152 \\
\hline $\mathrm{H}$ & -1.263 & 0.589 & -1.067 \\
\hline $\mathrm{H}$ & 1.201 & 2.223 & 2.077 \\
\hline $\mathrm{H}$ & 1.242 & 4.419 & 0.895 \\
\hline $\mathrm{H}$ & -0.080 & 4.727 & -1.190 \\
\hline C & 0.000 & 0.000 & 1.288 \\
\hline C & 0.000 & -1.233 & 0.577 \\
\hline C & -0.678 & -2.358 & 1.133 \\
\hline $\mathrm{C}$ & 0.721 & -1.430 & -0.641 \\
\hline C & -0.690 & -3.580 & 0.476 \\
\hline $\mathrm{H}$ & -1.201 & -2.223 & 2.077 \\
\hline C & 0.774 & -2.681 & -1.245 \\
\hline $\mathrm{H}$ & 1.263 & -0.589 & -1.067 \\
\hline C & 0.053 & -3.753 & -0.704 \\
\hline $\mathrm{H}$ & -1.242 & -4.419 & 0.895 \\
\hline $\mathrm{H}$ & 1.358 & -2.824 & -2.152 \\
\hline $\mathrm{H}$ & 0.080 & -4.727 & -1.190 \\
\hline
\end{tabular}

\begin{tabular}{|c|c|c|c|}
\hline \multicolumn{5}{|c|}{ Table S12. Cartesian coordinates of T-6 calculated the B97D3/def2-TZVP level of theory. } \\
\hline Atomic Symbol & $\mathrm{X}$ & $\mathrm{y}$ & $\mathrm{Z}$ \\
\hline $\mathrm{C}$ & -0.570 & 2.985 & -1.295 \\
$\mathrm{C}$ & -0.561 & 1.668 & -0.859 \\
$\mathrm{C}$ & 0.000 & 1.322 & 0.412 \\
$\mathrm{C}$ & 0.527 & 2.380 & 1.212 \\
$\mathrm{C}$ & 0.503 & 3.693 & 0.761 \\
$\mathrm{C}$ & -0.041 & 4.008 & -0.494 \\
$\mathrm{H}$ & -0.999 & 3.226 & -2.267 \\
$\mathrm{H}$ & -0.984 & 0.878 & -1.475 \\
$\mathrm{H}$ & 0.951 & 2.138 & 2.184 \\
$\mathrm{H}$ & 0.914 & 4.483 & 1.386 \\
$\mathrm{H}$ & -0.055 & 5.038 & -0.841 \\
$\mathrm{C}$ & 0.000 & 0.000 & 0.864 \\
$\mathrm{C}$ & 0.000 & -1.322 & 0.412 \\
$\mathrm{C}$ & -0.527 & -2.380 & 1.212 \\
$\mathrm{C}$ & 0.561 & -1.668 & -0.859 \\
$\mathrm{C}$ & -0.503 & -3.693 & 0.761 \\
$\mathrm{H}$ & -0.951 & -2.138 & 2.184 \\
$\mathrm{C}$ & 0.570 & -2.985 & -1.295 \\
$\mathrm{H}$ & 0.984 & -0.878 & -1.475 \\
$\mathrm{C}$ & 0.041 & -4.008 & -0.494 \\
$\mathrm{H}$ & -0.914 & -4.483 & 1.386 \\
$\mathrm{H}$ & 0.999 & -3.226 & -2.267 \\
$\mathrm{H}$ & 0.055 & -5.038 & -0.841 \\
\hline \multicolumn{3}{|c|}{$\mathrm{E}=-501.0996903, \mathrm{ZPE}=0.1790838$} & \\
\hline
\end{tabular}




\begin{tabular}{|c|c|c|c|}
\hline \multicolumn{2}{|c|}{ Table S13. Cartesian coordinates of S-10a calculated at the B97D3/def2-TZVP level of theory. } \\
\hline Atomic Symbol & $\mathrm{X}$ & $\mathrm{y}$ & $\mathrm{Z}$ \\
\hline C & -3.690 & -2.649 & -0.804 \\
C & -3.078 & -1.404 & -0.017 \\
C & -1.844 & -1.244 & 0.596 \\
C & -1.271 & -2.395 & 0.553 \\
C & -1.922 & -3.620 & -0.157 \\
C & -3.124 & -3.755 & -1.368 \\
H & -4.614 & -2.762 & -1.222 \\
H & -3.509 & -0.544 & 1.120 \\
H & -0.325 & -2.286 & 1.051 \\
H & -1.486 & -4.483 & -0.215 \\
C & -3.613 & -4.725 & 0.004 \\
C & -1.148 & 0.000 & 0.020 \\
C & -1.842 & 1.246 & -0.591 \\
C & -1.264 & 2.395 & 0.712 \\
C & -3.080 & 1.408 & -0.552 \\
H & -1.914 & 3.621 & -1.110 \\
C & -0.316 & 2.286 & 0.796 \\
H & -3.691 & 2.653 & 1.215 \\
C & -3.515 & 0.548 & 0.152 \\
H & -3.120 & 3.758 & -1.048 \\
H & -1.474 & 4.484 & 1.355 \\
C & -4.617 & 2.768 & 0.207 \\
I & -3.608 & 4.729 & -0.003 \\
F & 3.749 & -0.001 & 0.003 \\
F & 1.426 & -0.002 & -0.455 \\
& 4.261 & -1.179 & -0.801 \\
\hline
\end{tabular}

\begin{tabular}{|c|c|c|c|}
\hline Atomic Symbol & $x$ & $y$ & $z$ \\
\hline C & -3.112 & 3.197 & 0.944 \\
\hline C & -2.809 & 1.847 & 0.832 \\
\hline C & -1.819 & 1.397 & -0.096 \\
\hline C & -1.145 & 2.379 & -0.878 \\
\hline C & -1.454 & 3.726 & -0.746 \\
\hline C & -2.438 & 4.146 & 0.161 \\
\hline $\mathrm{H}$ & -3.872 & 3.519 & 1.653 \\
\hline $\mathrm{H}$ & -3.320 & 1.111 & 1.448 \\
\hline $\mathrm{H}$ & -0.383 & 2.055 & -1.583 \\
\hline $\mathrm{H}$ & -0.929 & 4.459 & -1.354 \\
\hline $\mathrm{H}$ & -2.675 & 5.203 & 0.260 \\
\hline C & -1.524 & 0.028 & -0.202 \\
\hline C & -2.173 & -1.209 & -0.125 \\
\hline C & -1.497 & -2.425 & 0.188 \\
\hline C & -3.578 & -1.282 & -0.398 \\
\hline C & -2.188 & -3.629 & 0.238 \\
\hline $\mathrm{H}$ & -0.430 & -2.397 & 0.390 \\
\hline C & -4.251 & -2.494 & -0.337 \\
\hline $\mathrm{H}$ & -4.108 & -0.369 & -0.657 \\
\hline C & -3.565 & -3.676 & -0.020 \\
\hline $\mathrm{H}$ & -1.650 & -4.543 & 0.481 \\
\hline $\mathrm{H}$ & -5.319 & -2.524 & -0.543 \\
\hline $\mathrm{H}$ & -4.098 & -4.623 & 0.022 \\
\hline C & 3.734 & -0.270 & 0.064 \\
\hline I & 1.513 & -0.073 & 0.001 \\
\hline $\mathrm{F}$ & 4.107 & -1.517 & -0.277 \\
\hline $\mathrm{F}$ & 4.194 & -0.013 & 1.301 \\
\hline $\mathrm{F}$ & 4.308 & 0.595 & -0.791 \\
\hline \multicolumn{4}{|c|}{$E=-1136.9432396, Z P E=0.1929117$} \\
\hline
\end{tabular}




\begin{tabular}{|c|c|c|c|}
\hline \multicolumn{2}{|c|}{ Table S15. Cartesian coordinates of 11a calculated at the B97D3/def2-TZVP level of theory. } \\
\hline Atomic Symbol & $\mathrm{X}$ & $\mathrm{y}$ & $\mathrm{Z}$ \\
\hline C & 3.164 & -2.541 & 1.312 \\
C & 2.527 & -1.339 & -0.066 \\
C & 1.638 & -1.232 & -0.857 \\
C & 1.409 & -2.380 & -0.584 \\
C & 2.062 & -3.574 & 0.504 \\
C & 2.938 & -3.659 & 2.167 \\
H & 3.832 & -2.614 & 1.662 \\
H & 2.688 & -0.472 & -1.695 \\
H & 0.723 & -2.306 & -1.211 \\
H & 1.888 & -4.444 & 0.725 \\
C & 3.439 & -4.598 & -0.392 \\
C & 0.967 & 0.017 & -0.101 \\
C & 1.592 & 1.278 & 0.304 \\
C & 0.894 & 2.445 & -0.361 \\
C & 2.986 & 1.411 & 0.420 \\
H & 1.544 & 3.664 & 0.567 \\
C & -0.156 & 2.365 & -0.271 \\
H & 3.619 & 2.644 & -0.694 \\
C & 3.545 & 0.542 & 0.126 \\
H & 2.907 & 3.778 & 0.753 \\
H & 0.986 & 4.535 & -0.504 \\
C & 4.678 & 2.718 & 0.216 \\
I & 3.410 & 4.737 & 0.448 \\
F & -3.512 & -0.001 & -0.531 \\
F & -1.249 & -0.076 & 1.291 \\
& -3.752 & -1.038 & 1.148 \\
\hline
\end{tabular}

\begin{tabular}{|c|c|c|c|}
\hline Atomic Symbol & $x$ & $y$ & $z$ \\
\hline C & -2.989 & 3.193 & 0.733 \\
\hline C & -2.619 & 1.854 & 0.674 \\
\hline C & -1.414 & 1.449 & 0.032 \\
\hline C & -0.602 & 2.471 & -0.524 \\
\hline C & -0.983 & 3.807 & -0.464 \\
\hline C & -2.178 & 4.181 & 0.161 \\
\hline $\mathrm{H}$ & -3.910 & 3.470 & 1.242 \\
\hline $\mathrm{H}$ & -3.245 & 1.102 & 1.146 \\
\hline $\mathrm{H}$ & 0.326 & 2.200 & -1.019 \\
\hline $\mathrm{H}$ & -0.343 & 4.564 & -0.913 \\
\hline $\mathrm{H}$ & -2.469 & 5.228 & 0.211 \\
\hline C & -1.069 & 0.047 & -0.003 \\
\hline C & -2.017 & -1.046 & -0.020 \\
\hline C & -1.762 & -2.311 & 0.567 \\
\hline C & -3.269 & -0.872 & -0.673 \\
\hline C & -2.708 & -3.329 & 0.525 \\
\hline $\mathrm{H}$ & -0.815 & -2.479 & 1.073 \\
\hline C & -4.208 & -1.897 & -0.714 \\
\hline $\mathrm{H}$ & -3.481 & 0.073 & -1.165 \\
\hline C & -3.938 & -3.133 & -0.113 \\
\hline $\mathrm{H}$ & -2.487 & -4.284 & 0.998 \\
\hline $\mathrm{H}$ & -5.151 & -1.737 & -1.233 \\
\hline $\mathrm{H}$ & -4.673 & -3.934 & -0.150 \\
\hline C & 4.244 & -0.205 & 0.037 \\
\hline I & 1.018 & -0.467 & -0.050 \\
\hline $\mathrm{F}$ & 4.739 & -1.241 & -0.641 \\
\hline $\mathrm{F}$ & 4.630 & -0.232 & 1.310 \\
\hline $\mathrm{F}$ & 4.562 & 0.949 & -0.542 \\
\hline \multicolumn{4}{|c|}{$E=-1136.9450171, Z P E=0.1936091$} \\
\hline
\end{tabular}




\begin{tabular}{|c|c|c|c|}
\hline \multicolumn{2}{|c|}{ Table S17. Cartesian coordinates of 13a calculated at the B97D3/def2-TZVP level of theory. } \\
\hline Atomic Symbol & $\mathrm{X}$ & $\mathrm{y}$ & $\mathrm{Z}$ \\
\hline C & -2.553 & 1.956 & -1.640 \\
$\mathrm{C}$ & -1.416 & 1.246 & -1.278 \\
$\mathrm{C}$ & -1.268 & 0.721 & 0.018 \\
$\mathrm{C}$ & -2.301 & 0.929 & 0.941 \\
C & -3.442 & 1.648 & 0.576 \\
$\mathrm{C}$ & -3.576 & 2.162 & -0.710 \\
H & -2.644 & 2.346 & -2.650 \\
H & -0.628 & 1.083 & -2.008 \\
H & -2.233 & 0.547 & 1.950 \\
H & -4.228 & 1.801 & 1.311 \\
H & -4.468 & 2.717 & -0.990 \\
C & 0.016 & -0.024 & 0.326 \\
C & 1.266 & 0.759 & -0.069 \\
C & 2.461 & 0.149 & -0.467 \\
C & 1.242 & 2.156 & 0.068 \\
C & 3.595 & 0.911 & -0.738 \\
H & 2.501 & -0.930 & -0.579 \\
C & 2.379 & 2.918 & -0.198 \\
H & 0.332 & 2.650 & 0.390 \\
C & 3.559 & 2.299 & -0.607 \\
H & 4.508 & 0.415 & -1.056 \\
H & 2.336 & 3.998 & -0.086 \\
H & 4.443 & 2.893 & -0.824 \\
C & 0.171 & -0.487 & 1.801 \\
F & -0.130 & -1.981 & -0.855 \\
F & 0.198 & 0.599 & 2.622 \\
F & -0.833 & -1.284 & 2.232 \\
\hline
\end{tabular}

\begin{tabular}{|c|c|c|c|}
\hline \multicolumn{2}{|c|}{ Table S18. Cartesian coordinates of S-10b calculated at the B97D3/def2-TZVP level of theory. } \\
\hline Atomic Symbol & $\mathrm{X}$ & $\mathrm{y}$ & $\mathrm{Z}$ \\
\hline $\mathrm{C}$ & 3.505 & 2.658 & -0.800 \\
$\mathrm{C}$ & 2.905 & 1.409 & -0.720 \\
$\mathrm{C}$ & 1.671 & 1.238 & -0.027 \\
$\mathrm{C}$ & 1.084 & 2.381 & 0.584 \\
$\mathrm{C}$ & 1.730 & 3.607 & 0.560 \\
$\mathrm{C}$ & 2.933 & 3.753 & -0.144 \\
$\mathrm{H}$ & 4.428 & 2.783 & -1.361 \\
$\mathrm{H}$ & 3.344 & 0.555 & -1.227 \\
$\mathrm{H}$ & 0.129 & 2.260 & 1.085 \\
$\mathrm{H}$ & 1.287 & 4.465 & 1.059 \\
$\mathrm{H}$ & 3.415 & 4.726 & -0.195 \\
$\mathrm{C}$ & 0.977 & 0.000 & 0.005 \\
$\mathrm{C}$ & 1.668 & -1.240 & 0.031 \\
$\mathrm{C}$ & 1.074 & -2.381 & -0.576 \\
$\mathrm{C}$ & 2.905 & -1.415 & 0.716 \\
$\mathrm{C}$ & 1.717 & -3.609 & -0.558 \\
$\mathrm{H}$ & 0.115 & -2.257 & -1.071 \\
$\mathrm{C}$ & 3.503 & -2.665 & 0.791 \\
$\mathrm{H}$ & 3.350 & -0.562 & 1.220 \\
$\mathrm{C}$ & 2.924 & -3.759 & 0.138 \\
$\mathrm{H}$ & 1.267 & -4.465 & -1.054 \\
$\mathrm{H}$ & 4.429 & -2.793 & 1.346 \\
$\mathrm{H}$ & 3.403 & -4.733 & 0.185 \\
$\mathrm{C}$ & -3.747 & 0.002 & -0.002 \\
$\mathrm{~F}$ & -4.232 & 1.187 & -0.429 \\
$\mathrm{~F}$ & -4.227 & -0.960 & -0.819 \\
$\mathrm{~F}$ & -4.235 & -0.224 & 1.235 \\
$\mathrm{Br}$ & -1.715 & 0.003 & 0.004 \\
\hline & & & \\
\hline
\end{tabular}




\begin{tabular}{|c|c|c|c|}
\hline \multicolumn{2}{|c|}{ Table S19. Cartesian coordinates of T-10b calculated at the B97D3/def2-TZVP level of theory. } \\
\hline Atomic Symbol & $\mathrm{X}$ & $\mathrm{y}$ & $\mathrm{Z}$ \\
\hline $\mathrm{C}$ & -4.207 & -2.253 & -0.186 \\
$\mathrm{C}$ & -3.472 & -1.084 & -0.176 \\
$\mathrm{C}$ & -2.047 & -1.101 & 0.047 \\
$\mathrm{C}$ & -1.419 & -2.360 & 0.154 \\
$\mathrm{C}$ & -2.172 & -3.519 & 0.043 \\
$\mathrm{C}$ & -3.568 & -3.478 & -0.280 \\
$\mathrm{H}$ & -5.290 & -2.216 & -0.494 \\
$\mathrm{H}$ & -3.968 & -0.137 & 0.135 \\
$\mathrm{H}$ & -0.338 & -2.397 & 0.328 \\
$\mathrm{H}$ & -1.671 & -4.468 & 0.128 \\
$\mathrm{H}$ & -4.150 & -4.391 & -0.306 \\
$\mathrm{C}$ & -1.321 & 0.084 & -0.155 \\
$\mathrm{C}$ & -1.464 & 1.468 & -0.982 \\
$\mathrm{C}$ & -0.757 & 2.385 & 0.863 \\
$\mathrm{C}$ & -2.308 & 2.004 & -0.806 \\
$\mathrm{C}$ & -0.898 & 3.753 & -1.755 \\
$\mathrm{H}$ & -0.103 & 1.993 & 1.019 \\
$\mathrm{C}$ & -2.444 & 3.375 & 1.517 \\
$\mathrm{H}$ & -2.839 & 1.318 & 0.190 \\
$\mathrm{C}$ & -1.742 & 4.259 & -1.450 \\
$\mathrm{H}$ & -0.351 & 4.436 & 1.798 \\
$\mathrm{H}$ & -3.095 & 3.764 & 0.322 \\
$\mathrm{H}$ & -1.849 & 5.332 & 0.102 \\
$\mathrm{C}$ & 3.628 & -0.476 & 1.207 \\
$\mathrm{~F}$ & 4.109 & 0.107 & -0.965 \\
$\mathrm{~F}$ & 4.240 & 0.055 & 0.150 \\
$\mathrm{Br}$ & 3.908 & -1.786 & -0.023 \\
\hline
\end{tabular}

\begin{tabular}{|c|c|c|c|}
\hline \multicolumn{2}{|c|}{ Table S20. Cartesian coordinates of 12b calculated at the B97D3/def2-TZVP level of theory. } \\
\hline Atomic Symbol & $\mathrm{X}$ & $\mathrm{y}$ & $\mathrm{Z}$ \\
\hline $\mathrm{C}$ & 1.715 & 2.817 & 0.258 \\
$\mathrm{C}$ & 0.644 & 1.935 & 0.274 \\
$\mathrm{C}$ & 0.564 & 0.860 & -0.653 \\
$\mathrm{C}$ & 1.631 & 0.718 & -1.577 \\
$\mathrm{C}$ & 2.696 & 1.608 & -1.584 \\
$\mathrm{C}$ & 2.748 & 2.667 & -0.672 \\
$\mathrm{H}$ & 1.756 & 3.618 & 0.992 \\
$\mathrm{H}$ & -0.125 & 2.039 & 1.031 \\
$\mathrm{H}$ & 1.604 & -0.096 & -2.293 \\
$\mathrm{H}$ & 3.494 & 1.478 & -2.311 \\
$\mathrm{H}$ & 3.587 & 3.357 & -0.678 \\
$\mathrm{C}$ & -0.554 & -0.044 & -0.604 \\
$\mathrm{C}$ & -1.864 & 0.257 & -0.079 \\
$\mathrm{C}$ & -2.686 & -0.722 & 0.529 \\
$\mathrm{C}$ & -2.383 & 1.573 & -0.185 \\
$\mathrm{C}$ & -3.940 & -0.394 & 1.029 \\
$\mathrm{H}$ & -2.318 & -1.738 & 0.620 \\
$\mathrm{C}$ & -3.640 & 1.890 & 0.311 \\
$\mathrm{H}$ & -1.797 & 2.332 & -0.693 \\
$\mathrm{C}$ & -4.427 & 0.912 & 0.927 \\
$\mathrm{H}$ & -4.543 & -1.163 & 1.504 \\
$\mathrm{H}$ & -4.018 & 2.903 & 0.201 \\
$\mathrm{H}$ & -5.411 & 1.163 & 1.314 \\
$\mathrm{C}$ & 2.133 & -0.906 & 1.477 \\
$\mathrm{~F}$ & 2.726 & -2.025 & 1.065 \\
$\mathrm{~F}$ & 1.148 & -1.174 & 2.336 \\
$\mathrm{~F}$ & 3.018 & -0.067 & 2.014 \\
$\mathrm{Br}$ & -0.288 & -1.815 & -1.290 \\
\hline & & & \\
\hline
\end{tabular}




\begin{tabular}{|c|c|c|c|}
\hline \multicolumn{2}{|c|}{ Table S21. Cartesian coordinates of 13b calculated at the B97D3/def2-TZVP level of theory. } \\
\hline Atomic Symbol & $\mathrm{X}$ & $\mathrm{y}$ & $\mathrm{Z}$ \\
\hline $\mathrm{C}$ & -2.627 & 2.023 & -1.253 \\
$\mathrm{C}$ & -1.467 & 1.275 & -1.092 \\
$\mathrm{C}$ & -1.306 & 0.415 & 0.007 \\
$\mathrm{C}$ & -2.343 & 0.325 & 0.942 \\
$\mathrm{C}$ & -3.506 & 1.082 & 0.782 \\
$\mathrm{C}$ & -3.655 & 1.931 & -0.311 \\
$\mathrm{H}$ & -2.729 & 2.678 & -2.114 \\
$\mathrm{H}$ & -0.672 & 1.348 & -1.828 \\
$\mathrm{H}$ & -2.262 & -0.322 & 1.805 \\
$\mathrm{H}$ & -4.297 & 1.001 & 1.523 \\
$\mathrm{H}$ & -4.564 & 2.515 & -0.432 \\
$\mathrm{C}$ & 0.004 & -0.348 & 0.102 \\
$\mathrm{C}$ & 1.224 & 0.565 & -0.013 \\
$\mathrm{C}$ & 2.429 & 0.156 & -0.592 \\
$\mathrm{C}$ & 1.152 & 1.842 & 0.564 \\
$\mathrm{C}$ & 3.532 & 1.008 & -0.610 \\
$\mathrm{H}$ & 2.501 & -0.828 & -1.042 \\
$\mathrm{C}$ & 2.258 & 2.690 & 0.552 \\
$\mathrm{H}$ & 0.229 & 2.173 & 1.027 \\
$\mathrm{C}$ & 3.452 & 2.278 & -0.039 \\
$\mathrm{H}$ & 4.457 & 0.674 & -1.074 \\
$\mathrm{H}$ & 2.181 & 3.675 & 1.003 \\
$\mathrm{H}$ & 4.312 & 2.942 & -0.057 \\
$\mathrm{C}$ & 0.163 & -1.224 & 1.381 \\
$\mathrm{~F}$ & 0.143 & -0.432 & 2.486 \\
$\mathrm{~F}$ & -0.815 & -2.144 & 1.531 \\
$\mathrm{Br}$ & 1.338 & -1.885 & 1.392 \\
\hline & -0.029 & -1.709 & -1.429 \\
\hline
\end{tabular}

Table S22. Relative energies of T-6, S-6, T-10a and S-10a at different levels of theory. All energies in $\mathrm{kcal} / \mathrm{mol}$.

\begin{tabular}{|c|c|c|c|c|}
\hline & T-6 & S-6 & T-10a & S-10a \\
\hline B97-D3/def2-TZVP & 0.0 & 6.1 & -6.1 & -10 \\
\hline B97-D3/def2-TZVP//CHARMM & 0.0 & 5.3 & - & - \\
\hline CAS(8,8)MP2/6-31G* & 0.0 & 9.2 & - & - \\
\hline BLYP-D3/def2-TZVP & 0.0 & 3.3 & -5.9 & -13.4 \\
\hline B3LYP-D3/def2-TZVP & 0.0 & 5.7 & -5.0 & -8.8 \\
\hline B3LYP-D3/6-311G** & 0.0 & 5.7 & -5.4 & -9.0 \\
\hline B3LYP/6-311G** & 0.0 & 6.3 & -1.1 & -3.9 \\
\hline M06-2X/def2-TZVP & 0.0 & 6.8 & -4.3 & -3.9 \\
\hline WB97X/def2-TZVP & 0.0 & 8.7 & -4.0 & -1.8 \\
\hline WB97XD/def2-TZVP & 0.0 & 7.6 & -4.3 & -3.7 \\
\hline
\end{tabular}




\section{References}

1. Gaussian 09, Revision D.01, Frisch, M. J.; Trucks, G. W.; Schlegel, H. B.; Scuseria, G. E.; Robb, M. A.; Cheeseman, J. R.; Scalmani, G.; Barone, V.; Mennucci, B.; Petersson, G. A.; Nakatsuji, H.; Caricato, M.; Li, X.; Hratchian, H. P.; Izmaylov, A. F.; Bloino, J.; Zheng, G.; Sonnenberg, J. L.; Hada, M.; Ehara, M.; Toyota, K.; Fukuda, R.; Hasegawa, J.; Ishida, M.; Nakajima, T.; Honda, Y.; Kitao, O.; Nakai, H.; Vreven, T.; Montgomery, J. A., Jr.; Peralta, J. E.; Ogliaro, F.; Bearpark, M.; Heyd, J. J.; Brothers, E.; Kudin, K. N.; Staroverov, V. N.; Kobayashi, R.; Normand, J.; Raghavachari, K.; Rendell, A.; Burant, J. C.; Iyengar, S. S.; Tomasi, J.; Cossi, M.; Rega, N.; Millam, J. M.; Klene, M.; Knox, J. E.; Cross, J. B.; Bakken, V.; Adamo, C.; Jaramillo, J.; Gomperts, R.; Stratmann, R. E.; Yazyev, O.; Austin, A. J.; Cammi, R.; Pomelli, C.; Ochterski, J. W.; Martin, R. L.;

Morokuma, K.; Zakrzewski, V. G.; Voth, G. A.; Salvador, P.; Dannenberg, J. J.; Dapprich, S.; Daniels, A. D.; Farkas, Ö.; Foresman, J. B.; Ortiz, J. V.; Cioslowski, J.; Fox, D. J. Gaussian, Inc., Wallingford CT 2009.

2. Yamamoto, N.; Vreven, T.; Robb, M. A.; Frisch, M. J.; Schlegel, H. B. Chem. Phys. Lett. 1996, 250, $373-378$

3. Hay, P. J.; Wadt, W. R. J. Chem. Phys. 1985, 82, 299-310.

4. Head-Gordon, M.; Pople, J. A.; Frisch, M. J. Chem. Phys. Lett.1988, 153, 503-506.

5. McDouall, J. J.; Peasley, K.; Robb, M. A. Chem. Phys. Lett. 1988, 148, 183-189.

6. Abegg, P. W.; Ha, T. K. Mol. Phys. 1974, 27, 763-67. 